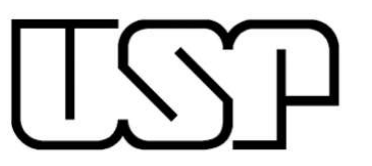

UNIVERSIDADE DE SÃO PAULO FACULDADE DE SAÚDE PÚBLICA

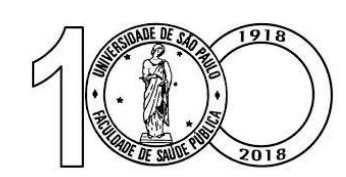

LEANDRA ANTUNES

ANÁLISE DE ACIDENTE DE TRABALHO SOB UMA

PERSPECTIVA ORGANIZACIONAL: ESTUDO DE CASO NO SETOR FERROVIÁRIO

SÃO PAULO

2018 


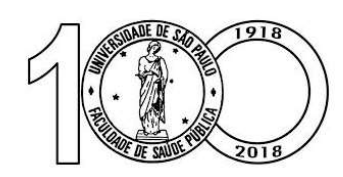

\title{
LEANDRA ANTUNES
}

\author{
ANÁLISE DE ACIDENTE DE TRABALHO SOB \\ UMA PERSPECTIVA ORGANIZACIONAL: \\ ESTUDO DE CASO NO SETOR FERROVIÁRIO
}

Dissertação apresentada ao Programa de PósGraduação em Ambiente, Saúde e Sustentabilidade, da Faculdade de Saúde Pública, da Universidade de São Paulo, para a obtenção do título de Mestra em Ciências.

Orientador: Prof. ${ }^{\circ}$ Dr ${ }^{o}$ Ildeberto Muniz de Almeida

Versão revisada

\section{SÃO PAULO}

2018 
Autorizo a reprodução e divulgação total ou parcial deste trabalho, por qualquer meio convencional ou eletrônico, para fins de estudo e pesquisa, desde que citada a fonte.

Catalogação da Publicação

Biblioteca/CIR: Centro de Informação e Referência em Saúde Pública

Faculdade de Saúde Pública da Universidade de São Paulo

Dados fornecidos pelo(a) autor(a)

Antunes, Leandra

- ANÁlISE DE ACIDENTE DE TRABALHO SOB UMA PERSPECTIVA

ORGANIZACIONAL: ESTUDO DE CASO NO SETOR FERROVIÁRIO /

Leandra Antunes; orientador Ildeberto Muniz de Almeida.

- São Paulo, 2018. 94 p.

Dissertação (Mestrado) - Faculdade de Saúde Pública da Universidade de São Paulo, 2018.

1. Acidente de Trabalho. 2. Ergonomia da Atividade. 3. Sustentabilidade Organizacional. 
ANTUNES, Leandra, Análise de Acidente de Trabalho sob uma perspectiva organizacional: estudo de casos no setor ferroviário - Faculdade de Saúde Pública da Universidade de São Paulo, São Paulo, 2018. 


\section{FOLHA DE APROVAÇÃO}

\section{ANTUNES, Leandra.}

Análise de Acidente de Trabalho sob uma perspectiva organizacional: estudo de caso no setor ferroviário

Dissertação apresenta ao Programa de Pós-Graduação Ambiente, Saúde e Sustentabilidade, da Faculdade de Saúde Pública, da Universidade de São Paulo, para obtenção do título de Mestra em Ciências.

Aprovado em

\section{BANCA EXAMINADORA}

Prof. Dr. Instituição:

Julgamento: Assinatura:

Prof. Dr. Instituição:

Julgamento: Assinatura:

Prof. Dr. Instituição: Assinatura: 


\section{DEDICATÓRIA}

À Rosária de Azevedo Melo (in memorian) por ter despertado a minha admiração pelo trabalho dos ferroviários. 


\section{AGRADECIMENTOS}

A Deus, pelas oportunidades pessoais e profissionais e por me dar saúde e forças para vencer os obstáculos e coragem para concluir mais uma importante etapa da minha vida.

Aos meus pais, Rosa Gonçalves de Mello Antunes e Luiz Roberto Antunes, por sempre acreditarem em minha capacidade. Em especial à minha mãe, por sempre estar presente com palavras motivadoras, fundamentais para a realização dos meus sonhos.

Ao meu marido, Edson Victor de Souza, meu porto seguro, companheiro de todas as horas, pela sua compreensão, respeito e incentivo ao longo dessa importante etapa da minha vida.

A minha filha, Ana Carolina Antunes de Souza, a quem não canso de dizer o quanto amo, pela compreensão nos momentos de ausência.

Ao meu orientador professor Ildeberto Muniz de Almeida (Pará) pelos valiosos ensinamentos e por me inspirar na busca de novos saberes. Foi uma honra tê-lo como orientador.

Aos professores da Faculdade de Saúde Pública da USP Frida Fischer, Gabriela Marques Di Giulio, José Marçal Jackson Filho, Leandro Luiz Giatti, Maria da Penha Vasconcellos e Renata Ferraz de Toledo, por compartilharem conhecimentos e experiências de vida. E, em especial, ao professor Rodolfo Andrade Gouveia Vilela por todo o apoio, constante disponibilidade, paciência e incentivo ao longo dessa jornada.

À Procuradora do Ministério Público do Trabalho da 2a Região Drª . Tatiana Simonetti, por viabilizar o campo de estudo para essa pesquisa e por ter confiado no projeto. E ao Gilberto Carletti pelo fundamental auxilio na coleta de dados.

Aos pesquisadores Dr $^{\mathrm{a}}$. Manoela Lopes, Dr ${ }^{\mathrm{a}}$. Silvana Zuccolotto e $\mathrm{Dr}^{\mathrm{o}}$. Hélio Neves pelas preciosas discussões.

A todos os entrevistados e participantes da pesquisa por disponibilizarem tempo e por compartilhar conhecimento ao longo da fase de coleta de dados.

Aos queridos amigos que cursaram disciplinas comigo Patricia Mendonça, Marli Reis, Rosicler Rodriguez, Carolina Abílio, Sandra Beltran, Simone Alves, Ana Yara, Luciana Pena e Willian Alves pela amizade, discussões e ajuda nessa caminhada. 
Aos membros do grupo PesquiAT pelo carinho com que fui recebida no grupo e pela troca de conhecimento que tem contribuído para o meu aprendizado.

Aos funcionários da Faculdade de Saúde Pública por serem gentis, atenciosos e eficientes no atendimento.

À minha prima Maria Amélia da Silva, pois nossos encontros são verdadeiros bálsamos para minha alma.

Aos meus colegas de trabalho Adriana Freitas, Alex Freire, Bruno Gomes, Claudio Scheidt, Diego Campos, Wanderli Coriolano e Wania Simões pela amizade e palavras de incentivo.

Enfim, a todos que contribuíram direta e indiretamente para realização deste trabalho.

\section{Muito Obrigada!}




\section{EPÍGRAFE}

"Não quero saber das partidas,

Das idas sem vindas

Que vão e não vêm..

Causando transtornos e danos,

Levando os sonhos nas rodas de um trem.

Eu quero é ouvir seu apito,

Acenar com agito em cada estação..

Sorrir ao sentir a chegada

Daqueles que foram buscando emoção!"

(Carmem Lúcia) 


\section{RESUMO}

ANTUNES, L. Análise de Acidente de Trabalho sob uma Perspectiva

Organizacional: estudo de casos no setor ferroviário. 2018. 94 f. Dissertação (Mestrado)

- Faculdade de Saúde Pública, Universidade de São Paulo, São Paulo, 2018.

Introdução - O transporte ferroviário metropolitano de passageiros é um ambiente de trabalho complexo e envolve riscos para os trabalhadores, que podem acarretar em grave acidente de trabalho. Após realizar testes em novos trens, três trabalhadores caminhavam na via quando foram atingidos por trem e morreram. Objetivo - Contribuir para a disseminação da abordagem organizacional na análise de acidentes do trabalho, de modo a ultrapassar o conceito de culpa da vítima. Método - Estudo de caso realizado por meio de pesquisa em livros, artigos, jornais e documentação. Após essa etapa, foram realizadas entrevistas com trabalhadores da empresa e observações do trabalho. Foi utilizado o Modelo de Análise e Prevenção de Acidentes de Trabalho (MAPA), que propõe uma abordagem sistêmica do caso. Resultado - A análise do trabalho habitual mostrou falha no planejamento e organização das condições de trabalho, falha nas comunicações necessárias à coordenação de interações entre tarefas e falha na gestão da segurança do trabalho das empresas terceirizadas. A análise de mudanças mostrou que a realização da tarefa no período noturno era eventual, os trabalhadores terceirizados não conheciam o local, também mostrou que informações diferentes foram comunicadas por e-mail e por formulário interno, os trabalhadores ficaram sabendo da mudança do pátio dos trens apenas quando foram realizar a tarefa e com isso, houve atraso na tarefa, o trajeto de volta não foi planejado. A ampliação conceitual mostrou que o histórico de acidentes ocorridos na empresa não serviu de alerta, bem como, a valorização do trabalho prescrito não impede a ocorrência de acidentes, pois a tarefa ocorreu em situação de trabalho com variabilidades. Conclusão - o estudo demonstrou que quando o acidente de trabalho é tratado de maneira reducionista, como evento causado pelo comportamento inadequado sem considerar a complexidade nas formas de trabalho, a empresa deixa de identificar oportunidades de melhoria organizacional, além de não tratar de maneira preventiva os múltiplos aspectos que contribuíram para a ocorrência do evento.

Palavras-chave: acidente de trabalho, ergonomia da atividade, sustentabilidade organizacional 


\section{ABSTRACT}

ANTUNES, L. Analysis of work accident about na organizational perpective: case study in the railway sector. 2018. 94 f. Dissertação (Mestrado) - Faculdade de Saúde Pública, Universidade de São Paulo, São Paulo, 2018.

Introduction - Metropolitan passenger rail transport is a complex work environment and involves risks for workers, which can be availed in a serious work accident. What is done in new trios, three days of transport on the road were struck by train and died. Objective - Contribute to the dissemination of the organizational approach in the analysis of occupational accidents, in order to overcome the concept of guilt of the victim. Method a case study carried out through research in books, articles, newspapers and documents. After this stage, interviews were conducted with company workers and observations of the work. It was used the Model of Analysis and Prevention of Accidents at Work (MAPA), which presented a case systematic. Result - The analysis of the work has been frequent in the failure of the planning and organization of the working conditions, failure in the communications for the coordination of tasks between tasks and tasks in the security of outsourced companies. The information contained in this exhibitor informed that the data were not valid, and those who were not informed about the place, were also published. What you did was not planned. A conceptual increase that made the history of occurrence indexes in the company did not serve as an alert, as well as, the valuation of the prescribed work did not prevent the occurrence of accidents, but a work situation with variabilities. Conclusion - the study showed that the work accident is treated in a reductionist way, as the event was of inappropriate behavior without considering the forms of work, a company is no longer a sign of organizational change, besides not treating preventive aspects which contributed to the occurrence of the event.

Keywords: work accident, ergonomics of the activity, organizational sustainability 


\section{SUMÁRIO}

1. INTRODUÇÃO …........................................................................................................ 19

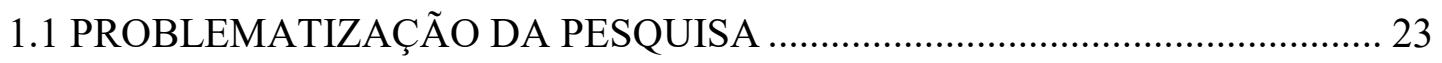

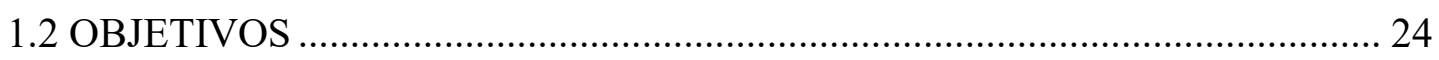

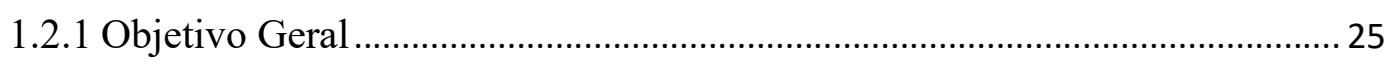

1.2.2 Objetivos Específicos.............................................................................. 25

1.3 ORGANIZAÇÃO DA DISSERTAÇÃO........................................................... 25

2. REVISÃO BIBLIOGRÁFICA ..................................................................... 26

2.1 CULPA DA VÍTIMA: UMA VISÃO REDUCIONISTA DA CAUSA DO

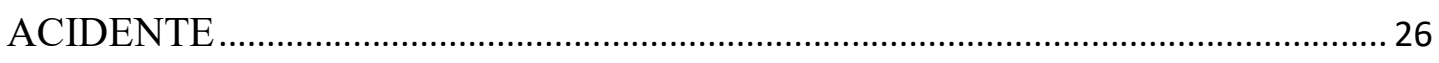

2.2 ASPECTOS ORGANIZACIONAIS ASSOCIADOS AO ACIDENTE DE

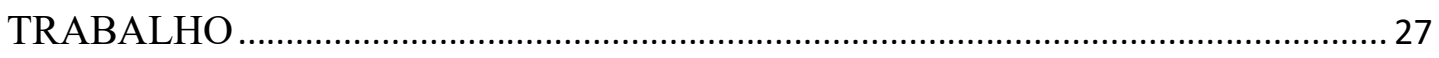

2.3 ENTENDENDO O TRABALHO HABITUAL E A VARIABILIDADE ............. 29

2.4 ANÁLISE DE MUDANÇAS................................................................................... 30

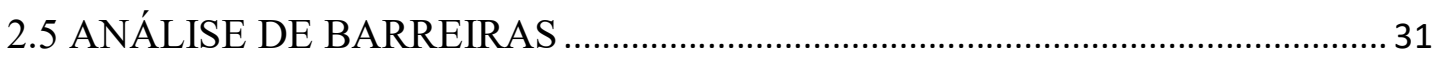

2.6 CONSEQUÊNCIAS DO ACIDENTE...................................................................... 33

3. ABORDAGEM METODOLÓGICA.................................................................... 35

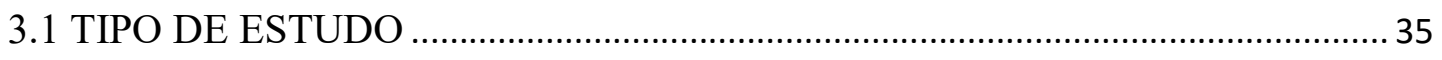

3.2 PESQUISA BIBLIOGRÁFICA.................................................................................

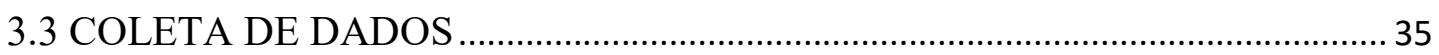

3.4 APLICAÇÃO DO MODELO DE ANÁLISE E PREVENÇÃO DE ACIDENTES

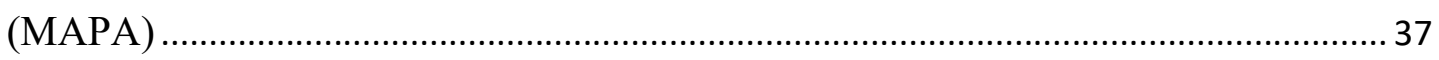

3.5 CONSIDERAÇÕES ÉTICAS .......................................................................... 39

4. ANÁLISE DO ACIDENTE DE TRABALHO....................................................... 40

4.1. O ACIDENTE DE TRABALHO EM ESTUDO ……………………………..... 40 
4.3. O CONTEXTO DA ATIVIDADE DESENVOLVIDA NO DIA DO ACIDENTE

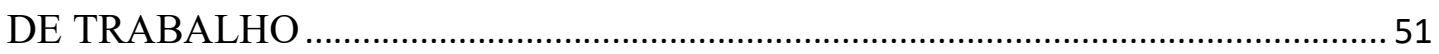

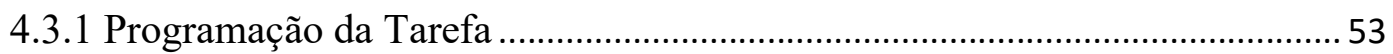

4.3.2 O Controle da Movimentação dos Trens na Ferrovia....................................... 55

4.3.3 O Trabalho do Maquinista que Conduzia o Trem Envolvido no Acidente .. 57

4.3.4 O Trabalho dos Maquinistas que Trabalharam nos Testes no Dia do Acidente

4.3.5 O Trabalho do Técnico em Manutenção ........................................................... 62

4.3.6 O Controle dos Serviços de Manutenção na Via Férrea.................................... 63

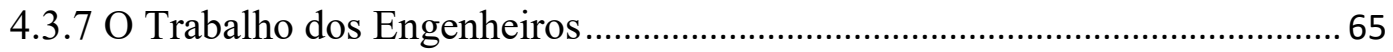

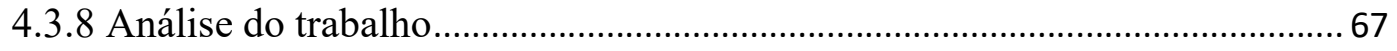

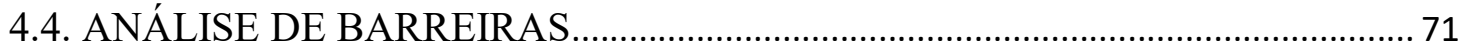

4.4.1 Síntese da Análise de Barreiras ....................................................................... 75

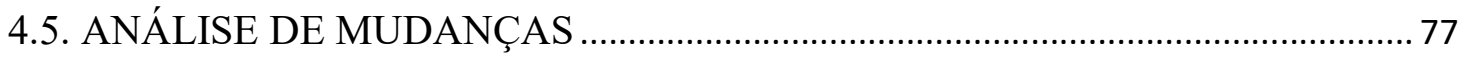

4.5.1 Síntese da Análise de Mudanças ....................................................................... 78

4.6. AMPLIAÇÃO CONCEITUAL ................................................................. 78

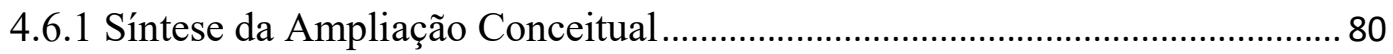

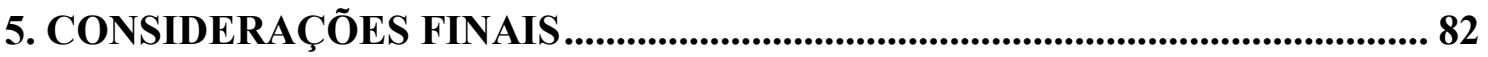

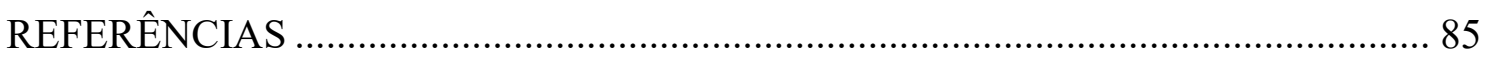

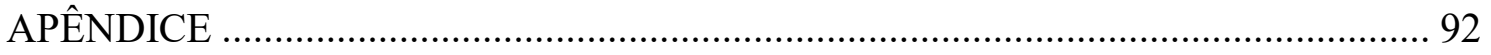

Termo de responsabilidade sobre os esclarecimentos éticos usados na pesquisa ..........93 


\section{LISTA DE SIGLAS E ABREVIATURAS}

ART - Anotação de Responsabilidade Técnica

CAT - Comunicação de Acidente de Trabalho

CBTU - Companhia Brasileira de Trens Urbanos

CIM - Centro de Informação da Manutenção

$\mathrm{CCO}$ - Centro de Controle Operacional

CIPA - Comissão Interna de Prevenção de Acidentes

CNAE - Classificação Nacional de Atividades Econômicas

CPTM - Companhia Paulista de Trens Metropolitanos

CTB - Companhia de Transportes do Estado da Bahia

EPI - Equipamento de Proteção Individual

EPC - Equipamento de Proteção Coletiva

ERA - European Union Agency for Railways

FSP - Faculdade de Saúde Pública

INSS - Instituto Nacional do Seguro Social

LTCAT - Laudo Técnico das Condições Ambientais do Trabalho

MAPA - Modelo de Análise e Prevenção de Acidentes

MPT - Ministério Público do Trabalho

MTPS - Ministério do Trabalho e Previdência Social

NR - Norma Regulamentadora

PCMSO - Programa de Controle Médico de Saúde Ocupacional

PPRA - Programa de Prevenção de Riscos Ambientais

SESMT - Serviço Especializado em Engenharia de Segurança e Medicina do Trabalho

TRENSURB - Empresa de Trens Urbanos de Porto Alegre

UNESP - Universidade Estadual Paulista "Júlio de Mesquita Filho"

USP - Universidade de São Paulo

VISAT - Vigilância em Saúde do Trabalhador 


\section{LISTA DE ILUSTRAÇÕES}

Figura 1 - Modelo do "Queijo-Suíço" 32

Figura 2 - Diagrama Bow-Tie ou Gravata-borboleta 32

Figura 3 - Mortes em linhas férreas na Europa 34

Figura 4 - Representação esquemática da localização do Pátio A e Pátio B 41

Figura 5 - Representação esquemática do trajeto das vítimas e trajeto dos 41 maquinistas

Figura 6 - Foto registrada no dia do acidente 42

Figura 7 - Linha do tempo da evolução histórica da administração das 43 ferrovias

Figura 8 - Origem dos trabalhadores que estão na ativa 44

Figura 9 - Número de passageiros que utilizaram os trens metropolitanos por 46 ano (em milhões)

Figura 10 - Linha do tempo das colisões entre trens 46

Figura 11 - Linha do tempo das colisões ocorridas antes do acidente em estudo $\quad 50$

Figura 12 - Linha do tempo dos principais fatos que antecederam o acidente $\quad 54$

Figura 13 - Equipamento simulador de trem $\quad 58$

Figura 14 - Localização do trajeto do Pátio B até a Estação de trem mais 61 próxima

Figura 15 - Imagem de dentro do trem mostra o espaço entre a via onde ocorreu 61 o acidente e o guarda-corpo em trecho sobre avenida

Figura 16 - Trabalhadores acessando a via $\quad 64$

Figura 17 - Destacado em vermelho, os limites geográficos do Pátio B 74

Figura 18 - Encontro da via férrea operacional e via interna do Pátio B 74

Figura 19 - Foto da faixa lindeira no dia do acidente 75

$\begin{array}{ll}\text { Figura } 20 \text { - Sentido contrário - mão americana } & 79\end{array}$

Figura 21 - Sentido do trem no dia do acidente $\quad 80$ 


\section{LISTA DE TABELAS}

Tabela 1 - Rede brasileira de transporte ferroviário metropolitano de 20 passageiros

Tabela 2 - Número de óbitos registrados em empresas de Transporte 21 Metroferroviário de Passageiros por região do país e ano 


\section{LISTA DE QUADROS}

Quadro 1 - Síntese dos principais procedimentos do método 36

$\begin{array}{ll}\text { Quadro } 2 \text { - Descrição da atividade habitual } & 70\end{array}$

Quadro 3 - Análise de barreiras 76

$\begin{array}{ll}\text { Quadro } 4 \text { - Análise de mudanças } & 78\end{array}$

Quadro 5 - Quadro síntese da ampliação conceitual 80

Quadro 6 - Resumo das análises realizadas por Instituições ou Comissões $\quad 81$ 


\section{APRESENTAÇÃ̃o}

Sou engenheira civil, engenheira de segurança do trabalho, especialista em gestão de projetos e auditora de sistemas de gestão da qualidade, meio ambiente, segurança e saúde do trabalho.

Ao longo do tempo, gerenciei, implantei e auditei Sistemas de Gestão da Qualidade, Segurança do Trabalho, Meio Ambiente e Saúde Ocupacional. No exercício do meu ofício, a análise de não conformidades e a busca pela melhoria continua na organização sempre guiaram o meu olhar.

Ao iniciar o Mestrado em Ambiente, Saúde e Sustentabilidade, o professor Rodolfo Vilela coordenava o projeto temático "Acidente de trabalho: da análise sócio técnica à construção social de mudanças", propôs que fosse utilizado Modelo de Análise e Prevenção de Acidentes, sob a orientação do professor Ildeberto Muniz de Almeida. Naquele momento surgiu o interessante desafio de realizar análise da segurança do trabalho com foco na melhoria organizacional.

Espero que o conhecimento produzido nesse estudo estimule processos de trabalho saudáveis, essenciais para a sustentabilidade das organizações. 


\section{INTRODUÇÃO}

O transporte ferroviário metropolitano de passageiros é um modal que se presta a um importante papel para a sociedade, favorecendo a articulação de regiões e o deslocamento de pessoas para o trabalho e lazer.

A região metropolitana de São Paulo e seu entorno, por exemplo, recebeu expressivos investimentos do mercado imobiliário para produção de condomínios e loteamentos fechados (GROSTEIN, 2015). Ainda segundo a autora, essa expansão da urbanização requer soluções para as demandas geradas pela vida urbana que envolvem a circulação não só de veículos, mas o transporte público para atender as necessidades de deslocamentos, conectando os principais centros urbanos.

Por muitos anos o planejamento do transporte urbano priorizou investimentos na construção de vias pavimentadas, como solução para o congestionamento das vias urbanas (ZANDONADE; MORETTI, 2012). Contudo, as populações, em especial dos grandes centros urbanos, continuam sofrendo com a superlotação de ônibus e o grande número de automóveis das vias urbanas (SANTOS; SOBRAL, 2014).

Para melhorar a sustentabilidade e a qualidade de vida, investimento em transporte ferroviário metropolitano de passageiros é uma alternativa que permite o deslocamento rápido de muitas pessoas, sem gerar poluição ambiental (ANPTRILHOS, 2016).

O transporte ferroviário metropolitano de passageiros no Brasil possui 802,9 quilômetros de extensão de via permanente (tabela 1). De uma maneira geral, mais de quatro milhões de passageiros utilizam diariamente os trens metropolitanos de passageiros, ao longo de 802,9 quilômetros de vias dispostas em várias cidades brasileiras, como mostra a Tabela 1. 
Tabela 1 - Rede brasileira de transporte ferroviário metropolitano de passageiros.

\begin{tabular}{|c|c|c|c|}
\hline EMPRESAS & MUNICÍPIOS ATENDIDOS & $\begin{array}{l}\text { EXTENSÃO } \\
\underset{(\mathbf{k m})}{ }\end{array}$ & $\begin{array}{l}\text { PASSAGEIROS } \\
\text { Média diária } \\
\text { (mil) em } 2015 \\
\end{array}$ \\
\hline \multirow{5}{*}{$\begin{array}{l}\text { Companhia Brasileira } \\
\text { de Trens Urbanos } \\
\text { (CBTU) }\end{array}$} & $\begin{array}{l}\text { Recife, Jaboatão dos Guararapes, } \\
\text { Camaragibe e Cabo de Santo Agostinho }\end{array}$ & 71,5 & 374,7 \\
\hline & Belo Horizonte e Contagem & 28,1 & 202,5 \\
\hline & Natal, Extremóz e Ceará Mirim & 56,6 & 9,7 \\
\hline & $\begin{array}{l}\text { João Pessoa, Cabedelo, Bayeux e Santa } \\
\text { Rita }\end{array}$ & 30 & 7,3 \\
\hline & Maceió, Satuba e Rio Largo & 32,1 & 8,9 \\
\hline $\begin{array}{l}\text { Companhia Paulista } \\
\text { de Trens } \\
\text { Metropolitanos } \\
\text { (CPTM) }\end{array}$ & $\begin{array}{l}\text { São Paulo, Itapevi, Jandira, Barueri, } \\
\text { Carapicuiba, Osasco, Jundiai, Varzea } \\
\text { Paulista, Campo Limpo Paulista, Francisco } \\
\text { Morato, Franco da Rocha, Caieiras, São } \\
\text { Caetano do Sul, Santo Andre, Maua, } \\
\text { Ribeirao Pires, Suzano, Ferraz de } \\
\text { Vasconcelos, Poa, Itaquaquecetuba, } \\
\text { Ribeirão Pires, Mogi das Cruzes }\end{array}$ & 257,3 & 2783 \\
\hline $\begin{array}{l}\text { Companhia de } \\
\text { Transportes do } \\
\text { Estado da Bahia } \\
\text { (CTB) }\end{array}$ & Salvador & 13,5 & 11,4 \\
\hline $\begin{array}{l}\text { Empresa de Trens } \\
\text { Urbanos de Porto } \\
\text { Alegre } \\
\text { (TRENSURB) }\end{array}$ & $\begin{array}{l}\text { Porto Alegre, Canoas, Esteio, Sapucaia do } \\
\text { Sul, São Leopoldo e Novo Hamburgo }\end{array}$ & 43,8 & 57,5 \\
\hline Supervia & $\begin{array}{l}\text { Rio de Janeiro, Duque de Caxias, Nova } \\
\text { Iguaçu, Nilópolis, Mesquita, Queimados, } \\
\text { São João de Meriti, Belford Roxo, Japeri, } \\
\text { Magé, Paracambi e Guapimirim }\end{array}$ & 270 & 700 \\
\hline Total & & 802,9 & 4.155 \\
\hline
\end{tabular}

Fonte: adaptado de CBTU (2015), CPTM (2015), CTB (2015), Trensurb (2015) e Supervia (2015)

Outro papel muito importante que o transporte ferroviário de passageiros representa para a sociedade é o significativo volume de emprego para muitas pessoas. A Companhia Brasileira de Trens Urbanos (CBTU), a Companhia Paulista de Trens Metropolitanos (CPTM), a Supervia, a Companhia de Transportes do Estado da Bahia (CTB) e a Empresa de Trens Urbanos de Porto Alegre (TRENSURB), juntas são responsáveis por cerca de 14.000 empregos no país, sem contar os trabalhadores de empresas terceirizadas, como os vigilantes entre outros cargos, que contribuem com a operação e manutenção do transporte ferroviário metropolitano de passageiros. 
No Brasil, o transporte sobre trilhos para passageiros é dividido entre as redes de metrô e de trem. Segundo Tani (2013), a tecnologia empregada na rede de trem é diferente da rede de metrô. No caso do metrô, a via é exclusiva para passageiros e visa atender as áreas mais centrais das cidades com trechos subterrâneos. Apesar da diferença tecnológica, as empresas que administram as redes de trem e as empresas que administram as redes de metro estão incluídas na mesma Classificação Nacional de Atividades Econômicas (CNAE).

O Anuário Estatístico de Acidentes do Trabalho, promovido pelo Ministério do Trabalho e Previdência Social (MTPS), registrou vinte e cinco óbitos no período de 2009 à 2014 em empresas Classificadas no CNAE correspondente ao Transporte Metroferroviário de Passageiros Brasileiro (tabela 2).

Tabela 2 - Número de óbitos registrados em empresas de Transporte Metroferroviário de Passageiros por região do país e ano. Brasil, 2009-2014.

\begin{tabular}{cccccccc}
\hline Região & $\mathbf{2 0 0 9}$ & $\mathbf{2 0 1 0}$ & $\mathbf{2 0 1 1}$ & $\mathbf{2 0 1 2}$ & $\mathbf{2 0 1 3}$ & $\mathbf{2 0 1 4}$ & Total \\
\hline Nordeste & & & & 1 & 1 & & 02 \\
Sudeste & 1 & 2 & 7 & 4 & 2 & 5 & 21 \\
Sul & & & 2 & & & & 2 \\
\hline Total & 1 & 2 & 9 & 5 & 3 & 5 & 25
\end{tabular}

Fontes: Adaptado de Anuário Estatístico de Acidentes do Trabalho de 2014 e 2011

Estes números não representam o número efetivo de trabalhadores que vieram à óbito em decorrência de acidentes ocorrido no ambiente de trabalho. Eles não incluem os vigilantes de estações e trabalhadores de empresas prestadoras de serviços, pois não são computados como trabalhadores de empresas de Transporte Metroferroviário de Passageiros.

O ambiente de trabalho no setor de transporte ferroviário de passageiros é complexo e envolve uma série de riscos para os trabalhadores que, por sua vez, podem acarretar em graves acidentes do trabalho. Entre os possíveis riscos que os trabalhadores podem estar expostos, o atropelamento por trem é um risco apontado por vários autores (FISCHER et al; 2004; SOUZA E FRATINI, 2005; AREOSA, 2014; PANTUZZO, 2015). 
Fischer et al (2004) analisaram 34 acidentes envolvendo maquinistas de trens urbanos no Rio Grande do Sul, com o objetivo de identificar fatores causais dos acidentes ocorridos no período de 1987 à 1992, de 1994 à 1998 e 2000 a 2002. Os autores identificaram que o tipo de acidente mais frequente é o atropelamento ou suicídio de usuário $(23,5 \%)$, que ratificam a carga psíquica do maquinista, cujas consequências são o estado de tensão no dia-a-dia e o sentimento de culpa pelo atropelamento.

Queda de trabalhador com e sem diferença de nível surgem ambas com 20,6\% dos acidentes. Nestes casos, a chuva amplia o risco de queda no lastro da via permanente e na escada de acesso ao trem (FISCHER et al ;2004).

Outro ponto relevante apontado no mesmo estudo é que a pressão pelo cumprimento de horário e/ou as poucas horas de sono, no caso de maquinistas com revezamento noturno, também são fatores que podem ter contribuído com a ocorrência dos acidentes (FISCHER et al; 2004).

Segundo Souza e Fratini (2005), durante a $63^{\mathrm{a}}$ reunião da Comissão Metroferroviária da Associação Nacional de Transportes Público (ANTP), o Grupo de Trabalho de Gestão de Riscos identificou a necessidade das operadoras do transporte ferroviário investirem em tecnologias relacionadas a sistemas de prevenção de atropelamentos.

Em estudo sobre a percepção de risco dos trabalhadores no setor ferroviário em Portugal, maquinistas relataram que colidir com outro trem ou atropelar uma pessoa estão entre os maiores medos que têm no ambiente de trabalho. A mesma pesquisa ainda apresenta relatos de trabalhadores que necessitam de apoio psicológico, justamente por terem presenciado situações de atropelamento e retirada do corpo da vítima para liberação da via (AREOSA, 2014).

A equipe que atua na manutenção da via permanente está sujeita ao atropelamento durante a inspeção da via permanente, em especial na inspeção e manutenção dos dormentes, na manutenção de lastro, na soldagem de trilhos e nos serviços de poda, roçada, limpeza de canaletas e recolhimento de lixo (PANTUZZO, 2015). O autor observou na empresa de transporte ferroviário onde foi realizada a pesquisa como se dá 
uma das interfaces entre a operação dos trens e a necessidade de dispor de pessoal na via para manutenção:

... as inspeções são realizadas no período diurno. A via não é paralisada, no entanto, o trecho a ser inspecionado é sinalizado de modo a impor a redução da velocidade dos trens. Embora o período noturno oferecesse maior segurança pela possibilidade de interdição do trecho a ser inspecionado, a falta de iluminação inviabiliza a execução dos serviços. (PANTUZZO, 2015, p. 34)

De acordo com Llory e Montmayeul (2014), é preciso reconhecer que a segurança ferroviária é complexa e que aprofundada análise das causas dos acidentes pode contribuir com a prevenção da ocorrência de novos eventos similares. Os autores salientam ainda que, a segurança precisa ser conduzida com base em estudos prevencionistas de risco e no estabelecimento de ações corretivas, de formação e reciclagem de pessoal e uma análise aprofundada das lições aprendidas com as experiências.

Neste sentido, analisar as causas dos acidentes de trabalho no setor ferroviário é um assunto de suma importância para os trabalhadores, para a sustentabilidade da organização e para a sociedade.

\subsection{PROBLEMATIZAÇÃO DA PESQUISA}

Em uma das empresas brasileiras de transporte ferroviário metropolitano de passageiros ocorreu um grave acidente envolvendo composição férrea em movimento, levando à morte três trabalhadores, sendo um próprio e dois terceiros.

Tal acidente deu origem a um inquérito civil, que por sua vez cita que a mesma possui histórico de acidentes por atropelamento.

Diante do histórico de acidentes do trabalho, a Faculdade de Saúde Pública da Universidade de São Paulo foi procurada pelo Ministério Público do Trabalho (MPT) 
com solicitação de apoio na análise das situações de trabalho que deram origem aos acidentes fatais.

A demanda veio ao encontro do interesse de pesquisar situações e tecnologias de risco em ambientes complexos, com vistas ao desenvolvimento da prevenção e do aprendizado organizacional, como consta no Projeto Temático intitulado "Acidente de Trabalho da análise sócio técnica à construção social de mudanças”.

De maneira geral, morte de trabalhadores após atropelamento merece investigação em profundidade, uma vez que as análises efetuadas pela empresa em estudo, até então, se restringiram a causas proximais, sem abarcar aspectos organizacionais, com foco na culpa dos trabalhadores, sem oportunidades de aprendizado organizacional.

Assim, este trabalho propõe investigar, como ponto central de seu desenvolvimento, a seguinte questão de pesquisa: quais as causas, de origem organizacional, que contribuíram com a ocorrência dos acidentes em uma empresa de Transporte Ferroviário Metropolitano de Passageiros?

Como premissas à questão enunciada, o trabalho aqui proposto procurou buscar a confirmação da seguinte proposição: se forem analisadas as causas de origem organizacional, torna-se possível a identificação de possíveis focos para medidas de prevenção que contribuam para a melhoria na segurança do trabalho no sistema em questão.

\subsection{OBJETIVOS}

Esta pesquisa tem como objetivo geral e objetivos específicos: 


\subsubsection{Objetivo Geral}

Contribuir para a disseminação da abordagem organizacional na análise de acidentes do trabalho, de modo a ultrapassar o conceito de culpa da vítima.

\subsubsection{Objetivos Específicos}

- Analisar o acidente de trabalho por atropelamento em via férrea, contemplando análise organizacional da segurança.

- Contribuir com dados empíricos para processo coletivo de aprendizagem organizacional.

- Formular recomendações de ações para prevenção de novos acidentes do trabalho por atropelamento.

\subsection{ORGANIZAÇÃO DA DISSERTAÇÃO}

No primeiro capítulo, buscou-se tecer uma reflexão sobre o ambiente de trabalho no setor ferroviário e a percepção dos trabalhadores do setor, além da problematização da pesquisa e apresentação dos objetivos geral e específicos. No segundo capítulo, realizouse revisão bibliográfica. No terceiro capítulo, apresentou-se a abordagem metodológica utilizada na realização da pesquisa, incluindo caracterização do tipo de estudo, dos sujeitos, dos instrumentos de investigação e análise de dados. No quarto capítulo, realizou-se análise do acidente de trabalho e discussão dos achados obtidos no processo de pesquisa. E por fim, o quinto capítulo traz as considerações finais sobre a pesquisa realizada. 


\section{REVISÃO BIBLIOGRÁFICA}

\subsection{CULPA DA VÍTIMA: UMA VISÃO REDUCIONISTA DA CAUSA DO ACIDENTE}

No meio técnico, ainda são realizadas análises de acidentes do trabalho apoiadas em modelos causais que não incluem as escolhas e as possíveis dificuldades que um trabalhador pode encontrar durante a execução do trabalho (Llory e Montmayeul, 2014).

Em algumas empresas ainda prevalece a visão reducionista de que os acidentes do trabalho seriam eventos causados pelo comportamento inadequado de operadores atrelado ao descumprimento dos padrões de segurança (Almeida e Vilela, 2010; Llory e Montmayeul, 2014).

Estudo baseado em setenta e um laudos de acidentes do trabalho, identificou que as vítimas costumam ser responsabilizadas pelos acidentes, mesmo em situações de elevado risco e sem condições mínimas de segurança para os trabalhadores (VILELA et al; 2004). Ainda segundo os autores, quem analisou os acidentes os tratou como algo simples, com causa única, sem explorar outras eventuais causas, sem fazer referência à condição disponível para o desenvolvimento da atividade e ao estado dos indivíduos.

As pessoas são propensas a esquecer que há complexidades nas formas de trabalho. Sendo assim, atribuir a culpa a vítima é uma maneira simplista de reduzir a responsabilidade sobre o acidente e as suas consequências (AREOSA, 2012).

O cenário torna-se mais preocupante à medida que o profissional de segurança do trabalho que conduz a análise dos acidentes tende a proteger a empresa a qual é subordinado e, por consequência, tende a transferir a responsabilidade aos trabalhadores vitimados (JACKSON FILHO et al, 2013). 


\subsection{ASPECTOS ORGANIZACIONAIS ASSOCIADOS AO ACIDENTE DE TRABALHO}

Ao analisar um acidente é preciso explorar o histórico de ocorrências relacionadas às suas origens; mapear os atores e suas inter-relações para que sejam identificadas disfunções organizacionais; também é importante analisar como se deram as decisões e o seus impactos na ocorrência do acidente.

Se explorada em profundidade e se apoiada em conceitos guia, a análise dos acidentes do trabalho pode possibilitar aprendizado organizacional (ALMEIDA et al 2014).

Apesar disso, em muitos casos, a conclusão da causa do acidente pode ser lavrada de maneira pouco aprofundada, dependendo da visão adotada para a elaboração da análise de acidente de trabalho.

A investigação das causas mais profundas está quase sempre relacionada a aspectos organizacionais, e permite uma avaliação de múltiplos aspectos que contribuíram com o acidente (LLORY e MONTMAYEUL, 2010).

Em 05 de outubro de 1999, dois trens colidiram de frente em Ladbroke Grove, subúrbio de Londres. Na ocasião, o maquinista não parou em sinal vermelho e conduziu o trem para uma via que estava sendo ocupada por composição de alta velocidade que trafegava em sentido contrário. Diante da iminente colisão, os controladores da ferrovia não tiveram tempo hábil para reagir e evitar o desastre. A colisão deixou 31 mortos e mais de 400 feridos (LLORY e MONTMAYEUL, 2010).

Ao invés de culpar o maquinista do trem que não parou no sinal e/ou os controladores que reagiram tardiamente e assim encerrar a análise do acidente, buscou-se analisar detalhadamente as situações de trabalho disponíveis para os maquinistas dos trens e para os controladores da ferrovia, antes do veredito final. Uma análise do acidente com maior grau de detalhamento, ou seja, com maior profundidade, permitiu que fossem evidenciadas falta de visibilidade e legibilidade do sinal devido a incidência do sol no 
instante do acidente, aspectos da complexidade do sistema de comunicação que comprometeu a agilidade no momento de emergência, por parte do controlador da ferrovia além de histórico de problemas de segurança mantidos intocados, todos envolvendo o mesmo sinal. (LLORY e MONTMAYEUL, 2010).

A reanálise do caso contribuiu para a tomada de ações corretivas de maneira mais assertiva, com foco preventivo.

Llory e Montmayeul (2010) sugerem que a organização seja explorada em três dimensões, como segue:

a) Dimensão temporal ou histórica: o período de incubação do acidente é caracterizado por um período onde não é dada atenção aos acontecimentos que trazem sinais da degradação do ambiente de trabalho. Portanto, é fundamental que seja verificado se as condições de segurança do trabalho estavam degradadas antes do acidente que está sendo analisado.

Os autores apresentam como exemplo que, no caso da análise do acidente com o trem ocorrido em Londres, a equipe responsável pela análise investigou a história do local da sinalização e descobriu que, anos antes do acidente, a sinalização foi trocada quando a via passou a ser bidirecional, além de passar a ter trens de alta velocidade. A investigação permitiu concluir que a sinalização da via permanente estava em local inadequado e com falha na legibilidade.

b) Dimensão transversal: analisar como a dinâmica das relações entre as áreas da empresa e sua interface com empresas terceirizadas, como por exemplo, flui de maneira integrada e cooperativa. Sendo assim, é importante que sejam pesquisados todos os atores envolvidos no evento que está sendo investigado, seus organismos de vinculação e a gerência responsável pela definição da organização do trabalho.

c) Dimensão vertical: averiguar a relação dos recursos humanos em toda a organização, desde o nível operacional até a alta gerência. Um olhar apurado 
para disfunções decorrentes seja da ausência da tomada de decisão, seja das ações tomadas é primordial na análise da dimensão vertical. Os autores acrescentam como exemplo, no caso de Ladbroke Grove, o fato de não se ter dado ouvidos aos pedidos de modificação da sinalização.

Na mesma obra os autores recomendaram a inclusão da dimensão comunicações na análise desse tipo de eventos. Isso significa explorar mecanismos existentes e adotados nas comunicações entre instâncias de mesmo nível e de diferentes níveis hierárquicos no sistema.

\subsection{ENTENDENDO O TRABALHO HABITUAL E A VARIABILIDADE}

A análise dos saberes do trabalhador está relacionada a diferença existente entre o trabalho real e o trabalho prescrito. Para Daniellou et al (2010), o trabalho prescrito, ou seja, a forma de execução do trabalho e a forma de usar as máquinas e ferramentas, as regras e o tempo atribuído para a execução nunca correspondem ao trabalho real desempenhado pelo trabalhador.

Para compreender o trabalho real desempenhado pelo trabalhador, a influência dos fatores organizacionais sobre as atividades e o surgimento dos agravos, é possível contar com a Ergonomia da atividade.

Hollnagel (2014) preconiza que o processo de análise de acidente de trabalho precisa incluir etapa de compreensão do cotidiano do trabalho, incluindo a identificação dos acertos e erros que ocorrem diariamente, para que efetivamente sejam compreendidas as razões que explicam o ocorrido.

Por definição, erros são ocorrências involuntárias. Eles podem ocorrer devido a desvio de um objetivo, norma ou regra. Em classificação bastante difundida Reason diferencia erros na execução do planejado, ou seja, a possibilidade de não fazer algo ou de não agir conforme o pretendido (lapsos e deslizes) e a possibilidade de se fazer o 
pensado e não alcançar o pretendido (engano “mistakes"). Para Daniellou et al. (2010), os principais tipos de erros estão vinculados a:

a) Uma confusão de percepção ou lapso, por exemplo, digitou 17236 no lugar de 17326.

b) Execução da regra, devido a uma situação mal caracterizada. Muitas vezes uma pessoa externa é que irá conseguir visualizar o erro.

c) Modo de implementação do conhecimento, quando o trabalhador precisa mobilizar um conhecimento para analisar uma situação e tomar uma decisão, principalmente em situações não habituais.

Amalberti (2016) acrescenta que para desconstruir a ligação entre o erro e o acidente, seria necessário analisar os saberes do trabalhador e a maneira que ele controla uma determinada situação.

Jackson et al (2015) citam que a Análise Ergonômica do Trabalho implica em compreender, do ponto de vista dos atores, como ocorrem as falhas do processo de trabalho. Sendo assim, a análise dos erros humanos com base na exclusiva análise dos desvios de comportamento seguro passa a ser uma abordagem inadequada.

\subsection{ANÁLISE DE MUDANÇAS}

A análise de mudanças é o processo que busca esclarecer as origens que contribuíram para a ocorrência das mudanças. Para tanto, são realizados questionamento que busquem identificar as causas mais profundas que contribuíram para a mudança ocorrida no acidente (ALMEIDA et al. 2014).

O processo pode identificar origens técnicas tais como, choque elétrico, intoxicação etc. Entretanto, a identificação de falhas na gestão, falhas na comunicação, falhas na manutenção e os aspectos sociais ou comportamentos que influenciaram nas 
decisões tomadas também podem surgir como fatores que contribuíram para a ocorrência do acidente (ALMEIDA et al. 2014).

\subsection{ANÁLISE DE BARREIRAS}

Segundo Reason (2000), na análise de acidentes organizacionais é importante considerar que os seres humanos estão sujeitos à falhas e os erros surgem como consequência de fatores sistêmicos que estão à montante. $\mathrm{O}$ autor cita que os erros podem ser considerados consequências, ao invés de causas. Sendo assim, o importante é compreender os motivos que explicam as falhas das barreiras e os fatores históricos que contribuíram com a incubação do acidente.

As barreiras permitem a proteção dos trabalhadores e são usados no controle de situação de risco ou perigo pelo controle de energia e transporte incontrolado de massa ou informação. De acordo com Hollnagel (2008), são divididas em físicas ou materiais, funcionais e simbólicas.

As barreiras físicas permitem o bloqueio físico e a propagação da energia, por exemplo, uma porta-corta fogo. As barreiras funcionais são pré-condição de uma ação, por exemplo um sistema de inter-travamento que bloqueia o sistema. E as barreiras simbólicas necessitam de interpretação para alcançar o propósito, por exemplo, as placas de sinalização, os alarmes etc (ALMEIDA E VILELA, 2010).

Reason (2000) compara barreiras com as fatias de um queijo suíço (figura 1), pelo fato das barreiras poderem apresentar falhas. Segundo a teoria, a presença de um furo em uma das camadas pode não gerar grandes consequências, mas se houver furos em diversas camadas, e os mesmos estiverem alinhados, surgem uma trajetória e a oportunidade da ocorrência de acidente. 


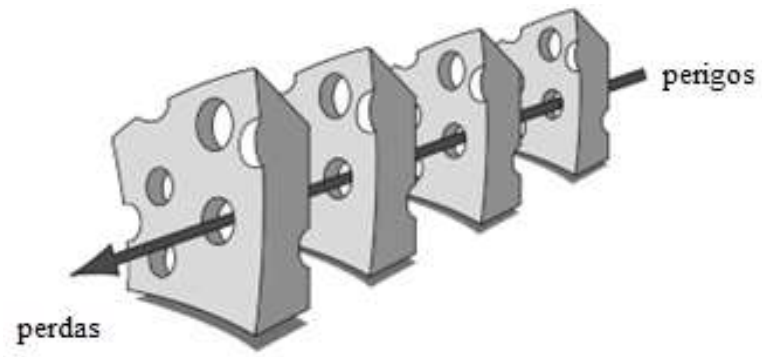

Figura 1 - Modelo do "Queijo Suíço" Fonte: REASON (2000)

O conceito de barreiras também é tratado no diagrama Bow-Tie, ou gravataborboleta. O diagrama foi desenvolvido para a indústria de alta tecnologia, mas com o passar do tempo a área de segurança do trabalho também passou a usá-lo, por permitir a compreensão de possíveis caminhos entre o perigo e o acidente, além de também compreender a influência do sistema de segurança sobre o evento, no caso o acidente (JACINTO, SILVA, 2010).

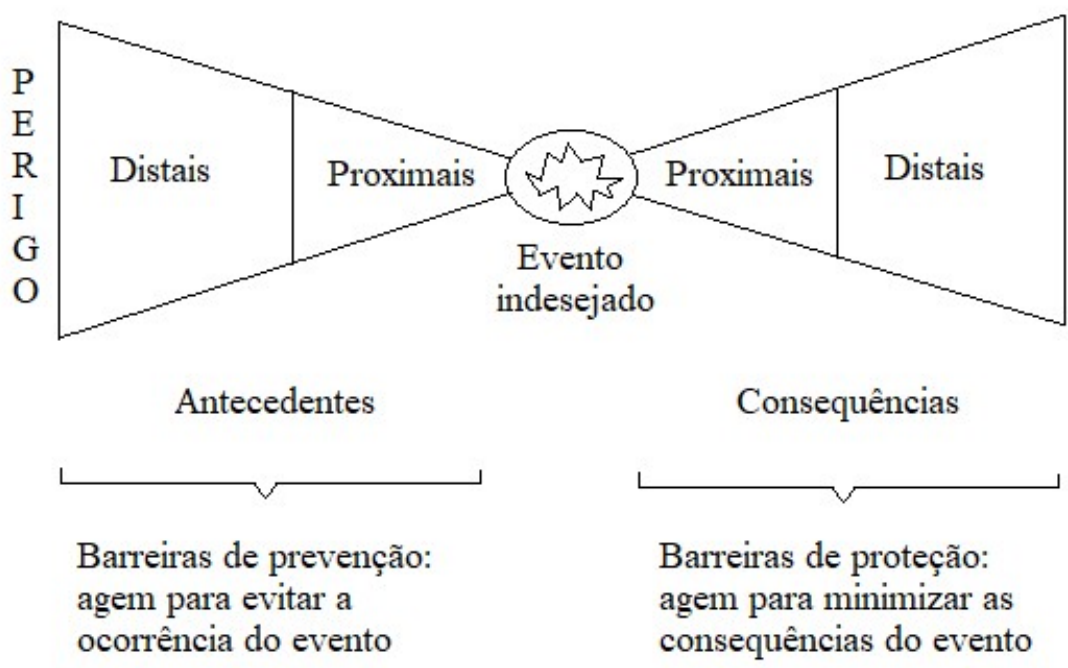

Figura 2 - Diagrama Bow-Tie ou Gravata-borboleta Fonte: Almeida e Vilela (2010) - Adaptado de Hale et al (2007)

A figura 2 apresenta o diagrama, onde o lado esquerdo inclui uma lista de potenciais perigos que podem conduzir a um acidente, enquanto o lado direito representa as diversas consequências possíveis. Entre os perigos e o evento indesejável, o diagrama apresenta barreiras de prevenção para evitar o evento indesejável. E entre o evento 
indesejável e as consequências, o diagrama apresenta barreiras de proteção para minimizar as consequências (JACINTO; SILVA, 2010).

Entre os principais benefícios do uso do diagrama é apontada a avaliação do desempenho da barreira, por exemplo, como se deu o tempo de resposta, o nível de eficiência e o nível de confiança, contribuindo de maneira acentuada com a gestão de riscos (JACINTO; SILVA, 2010).

No contexto da análise dos acidentes, a análise das barreiras contribui para a compreensão das falhas da proteção do trabalhador contra as nocividades presentes no sistema, sendo assim, um importante ponto de partida para o entendimento das falhas na gestão de segurança que levaram ao acidente (ALMEIDA et al, 2014). Em síntese, a análise de barreiras explica a ocorrência de acidentes como resultado ou produto da falta ou da falha de barreiras que deveriam ter mantido sob controle os perigos existentes e mitigado consequências de eventual descontrole dessa nocividade. Em conformidade com a noção de análise em profundidade ressalta-se a necessidade de esclarecer as razões que expliquem seja a falta seja a falha das barreiras em questão. Mais recentemente essa abordagem considera também a existência de barreiras de monitoramento da situação do sistema e de suas barreiras e suas eventuais contribuições para a segurança.

\subsection{CONSEQUÊNCIAS DO ACIDENTE}

Muito tem sido estudado sobre acidente envolvendo colisão de trem, descarrilamento de trem, acidentes em passagem de nível e até sobre pessoas que cometem suicídio na via. Este último principalmente em função do número expressivo de ocorrências notificadas.

Na Europa, segundo a Agência Ferroviária Européia, entre 2012 e 2014, 72\% das mortes ocorridas nas linhas férreas foram em virtude de pessoas que cometeram suicídio nas linhas férreas (ERA, 2016). 


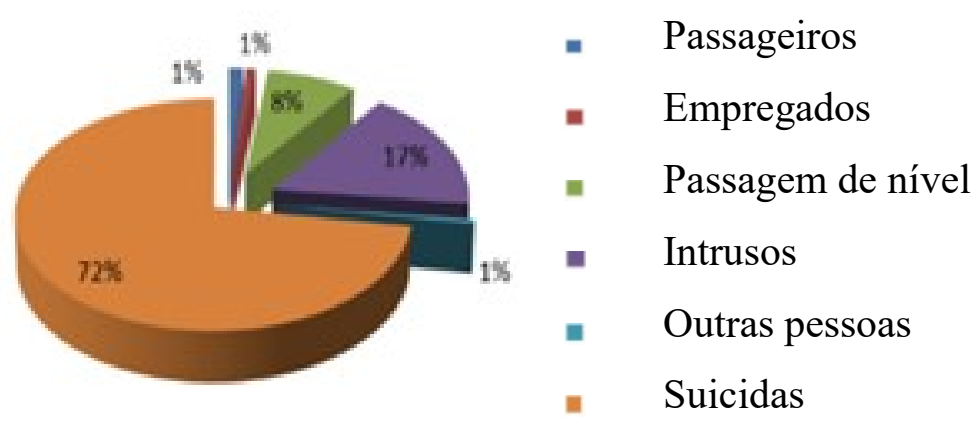

Figura 3 - Mortes em linhas férreas na Europa Fonte: adaptada de ERA (2016)

Dentro do contexto da relação do maquinista e o atropelamento, é importante considerar que por mais que o maquinista esteja atento durante a condução do trem, ao acionar o freio, a composição ainda percorre alguns metros até efetivamente parar. Sendo assim, estar atento não pode ser considerado como único meio para prevenção de atropelamentos.

Os acidentes que ocorrem nos trilhos comumente geram impacto psicológico no maquinista que conduzia o trem em casos de atropelamento. Ainda de acordo com o autor, há casos de maquinistas que desenvolvem distúrbios no sono e na concentração, tremor e aumento do batimento cardíaco nas primeiras 24 horas após o acidente. Também há casos de maquinistas que desenvolvem estresse pós-traumático após um acidente, além de depressão e fobia (CHAVDA, 2016). A representação desses eventos com o modelo da gravata-borboleta ajuda a evidenciar que o acidente não se encerra no momento de descontrole da nocividade potencial presente no sistema. Em outras palavras, que em muitos casos também está recomendada a busca ativa de efeitos tardios do ocorrido, inclusive para o operador envolvido. Quanto mais precoce a resposta do sistema a essas situações, melhores tendem a ser os resultados obtidos. 


\section{ABORDAGEM METODOLÓGICA}

\subsection{TIPO DE ESTUDO}

O desenvolvimento dessa pesquisa foi realizado por meio de um estudo de caso de natureza qualitativa e visa analisar área que pouco foi estudada, ou seja, morte de trabalhadores por atropelamento no setor ferroviário e sua relação com a estrutura organizacional.

O estudo de caso permite um entendimento de como os processos de trabalho acontecem de forma real, fornecendo a observação com melhores detalhes do contexto estudado (YIN, 2010). Com isso, a caracterização metodológica da pesquisa foi adotada no sentido de compreender as causas de origem organizacional que contribuíram para a ocorrência do acidente de trabalho.

\subsection{PESQUISA BIBLIOGRÁFICA}

Inicialmente a pesquisa contou com uma revisão bibliográfica em livros, trabalhos acadêmicos, artigos científicos e matérias da mídia, em linhas gerais, sobre o cenário e a importância do transporte ferroviário metropolitano, importância da análise organizacional para a investigação das causas do acidente no ambiente ferroviário e apresentação de modelos de análise de prevenção de acidentes que contemplam abordagem organizacional.

\subsection{COLETA DE DADOS}


A pesquisa incluiu consulta à documentação que integra o Inquérito Civil, a documentação da Empresa e notícias publicadas em jornais. Esses dados extraídos de fontes secundárias foram fundamentais para a exploração empírica do fenômeno.

O estudo também contemplou pesquisa de campo. Os representantes da Gerência de Desenvolvimento Organizacional e Recursos Humanos, Gerência Geral de Operações e Gerência Geral de Manutenção apresentaram o panorama dos trabalhos desenvolvidos por cada departamento. Além disso, foram realizadas observações e entrevistas nãoestruturadas com alguns atores que têm conhecimento sobre o trabalho desenvolvido na empresa.

O formato para as entrevistas foi o não-estruturado por permitir a liberdade de caminhar no sentido que for mais conveniente para o tema em discussão. E em relação à seleção dos atores, tomou-se como base a capacidade acumulada pelos atores de modo à suprir as informações necessárias (MARKONI; LAKATOS, 2010).

A seleção das áreas que seriam estudadas, por meio de observação das atividades e entrevistas com os trabalhadores, teve como partida a necessidade de compreender como se dá o trabalho das áreas que possuem interface com o acidente de trabalho em estudo.

O quadro 1 apresenta a síntese dos principais procedimentos do método.

Quadro 1 - Síntese dos principais procedimentos do método

\begin{tabular}{|l|l|l|}
\hline \multicolumn{1}{|c|}{ Instrumento } & \multicolumn{1}{|c|}{ Objetivo } & \multicolumn{1}{c|}{ Como } \\
\hline Análise de documentos & $\begin{array}{l}\text { Identificar as vítimas empresas; } \\
\text { Conhecer o trabalho prescrito; } \\
\text { Conhecer as barreiras; } \\
\text { Conhecer a gestão da segurança do } \\
\text { trabalho. }\end{array}$ & $\begin{array}{l}\text { Leitura de cento e cinquenta } \\
\text { documentos eletrônicos; } \\
\text { Leitura de vinte e seis } \\
\text { documentos em meio físico. }\end{array}$ \\
\hline Leitura de notícias & $\begin{array}{l}\text { Identificar o histórico dos acidentes } \\
\text { ocorridos na empresa; } \\
\text { Identificar o histórico da aquisição e } \\
\text { entrega de novos trens. }\end{array}$ & $\begin{array}{l}\text { Leitura das notícias publicadas } \\
\text { ao longo dos cinco anos que } \\
\text { antecederam o acidente em } \\
\text { estudo. }\end{array}$ \\
\hline $\begin{array}{l}\text { Apresentação das áreas, } \\
\text { observações e entrevistas }\end{array}$ & $\begin{array}{l}\text { Compreender o trabalho habitual; } \\
\text { Compreender as relações hierárquicas e } \\
\text { transversais; } \\
\text { Compreender a gestão e a cultura de } \\
\text { segurança. }\end{array}$ & \begin{tabular}{l} 
Sessenta e duas horas \\
\hline
\end{tabular} \\
\hline
\end{tabular}


Em complemento, foram realizadas viagens de trens na linha onde ocorreu o acidente, com o intuito de observar o trajeto percorrido pelo trem envolvido no acidente, a estação de trem mais próxima do local do acidente e o trajeto até o pátio mais próximo, bem como, o trajeto entre os pátios citados no caso.

\subsection{APLICAÇÃo DO MODELO DE ANÁLISE E PREVENÇÃo DE ACIDENTES (MAPA)}

Para a elaboração da reanálise de acidentes do trabalho foi utilizada a referência teórico-metodológica conhecida como Modelo de Análise e Prevenção de Acidentes (MAPA) proposto por Almeida e Vilela (2010), que recebeu como dados de entrada toda a informação decorrente da análise documental, das entrevistas e da observação de campo.

O MAPA é um método qualitativo-descritivo que guia a compreensão do acidente como evento único e que, se adequadamente analisado, pode evidenciar as falhas de origem gerencial, as falhas de concepção de sistemas, as falhas de gestão de segurança do trabalho, a gestão das variabilidades, entre outros aspectos que contribuem com a prevenção de acidentes (ALMEIDA E VILELA, 2010).

A aplicação do MAPA, segundo Almeida e Vilela (2010), pressupõe a aplicação de conceitos como guias para construção de uma rede de fatores relacionados à origem do acidente. Sendo eles:

a) Trabalho habitual: o analista precisa observar como o trabalho é realizado rotineiramente e quais os componentes da atividade, ou seja, quem são os indivíduos que desenvolvem o trabalho, quais as tarefas, quais os materiais, como é o meio de trabalho, quais as estratégias e modos operatórios usados no trabalho rotineiro e na vigência de variabilidades que demandem ajustes. Explica o acidente como fracasso de estratégias e modos operatórios usados anteriormente com sucesso no sistema e pelas condições do sistema que levaram a esse fracasso. 
b) Análise de mudanças: parte do princípio que uma mudança no sistema de trabalho contribuiu para a ocorrência do acidente. Seja ela relacionada à forma de organização, à gestão de pessoal, ao material, à forma de manutenção, à forma de comunicação, aos indivíduos presentes, por exemplo. O acidente é explicado pela ocorrência dessas mudanças e pelas condições do sistema que permitiram suas origens.

c) Análise das barreiras: consiste na identificação de perigos e riscos e quais as barreiras adotadas pela empresa para eliminar, monitorar ou mitigar a ocorrência de eventos indesejáveis. Explica o acidente pela falta ou falha de barreiras e pelas condições do sistema que permitiram as origens de tais faltas ou falhas.

d) Ampliação conceitual: que destaca a possibilidade de conceitos de diferentes campos do conhecimento, em especial daqueles que já tenham sido usados em análises de acidentes, permitirem novas leituras ou compreensões de aspectos ou fatos registrados na coleta de dados do acidente. O exemplo mais frequente é o de acidentes envolvendo comportamentos de tipo "omissões do acidentado" que, após "ampliação conceitual" passaram a ser entendidos como situações descritas na literatura como armadilhas cognitivas.

O MAPA foi aplicado por pesquisadores e membros de Centro de Referência em Saúde do Trabalhador (CEREST) em várias situações de trabalho, na construção civil, na distribuição de alimentos, frigorífico, por exemplo (ALMEIDA E VILELA, 2010).

O modelo proposto associa conceitos de uso em diferentes campos do conhecimento, de modo que pode contribuir de maneira positiva na análise de acidentes do trabalho em ambiente trabalho complexo, como no caso do setor ferroviário.

Silva (2015) comenta que a aplicação do MAPA na análise de acidentes do setor elétrico favoreceu a identificação de achados quanto às condições precárias de trabalho, além de tornar clara a importância da participação e dos conhecimentos dos trabalhadores no processo de análise de acidentes, principalmente no que tange às variabilidades. 
Donatelli (2013) aplicou o MAPA para analisar em profundidade acidentes do trabalho envolvendo material biológico em hospital. Segundo a autora, a identificação de aspectos como sobrecarga de trabalho, ritmo de trabalho e falhas na gestão da segurança foi possível devido à aplicação do MAPA na análise dos acidentes.

Hurtado (2016) aplicou o MAPA para analisar em profundidade acidentes do trabalho ocorridos em uma refinaria de petróleo. Segundo a autora, a aplicação do MAPA permitiu reconhecer que alguns fatores foram ignorados na investigação realizada internamente pela empresa.

Lopes (2012) aplicou o MAPA em acidente envolvendo dois trens e um ônibus, onde comparou a conclusão da análise de acidente baseada na teoria monocausal, com a conclusão da análise do acidente realizada com base no MAPA. A abordagem monocausal identificou que o erro humano foi o fator que promoveu o acidente enquanto que a aplicação do MAPA permitiu identificar falhas no sistema de barreiras e precariedades no sistema de organização do trabalho que contribuíram para a ocorrência do acidente.

\subsection{CONSIDERAÇÕES ÉTICAS}

Esta pesquisa foi aprovada pelo Comitê de Ética em Pesquisa da Faculdade de Saúde Pública da Universidade de São Paulo sob o comprovante 151190/2017.

O termo de responsabilidade sobre esclarecimentos éticos usados na pesquisa (apêndice) foi apresentado aos participantes da pesquisa, o qual foi assinado por duas testemunhas, que não participaram como sujeitos da pesquisa. $\mathrm{O}$ uso do termo de responsabilidade e não do termo de consentimento livre e esclarecido justifica-se pela necessidade de não coletar o nome ou assinatura dos sujeitos da pesquisa. Em conformidade com a Resolução 196/96 do Conselho Nacional de Saúde, foi respeitada a autonomia e a garantia do anonimato dos participantes, assegurando sua privacidade, quanto a dados confidenciais. 


\section{ANÁLISE DO ACIDENTE DE TRABALHO}

Acidentes do trabalho são eventos que possuem grande interface entre a situação do trabalho e os aspectos organizacionais. Sendo assim, analisar o acidente de trabalho em profundidade inclui a compreensão da rede de fatores que movem o funcionamento da organização.

\subsection{O ACIDENTE DE TRABALHO EM ESTUDO}

Por volta das 23 horas do dia anterior ao dia do acidente, um técnico em manutenção da empresa de transporte ferroviário, dois engenheiros de empresa terceira contratada para fornecimento de novos trens, um engenheiro estrangeiro de empresa terceira responsável pelo fornecimento do sistema de frenagem dos trens e quatro maquinistas da empresa de transporte ferroviário se encontraram no pátio $\mathrm{A}$ com o objetivo de realizar testes de frenagem em dois novos trens que estavam estacionados no pátio $\mathrm{B}$.

O grupo embarcou em um trem no Pátio A que os deixou próximo aos trens que seriam testados e que estavam estacionados no Pátio B (Figura 4). Na sequência, eles foram com os novos trens até o local do teste, que consiste em trecho de via permanente em rampa, localizado entre duas estações na mesma via férrea.

Por volta das 3 h50, após a realização dos testes, os trens foram estacionados no pátio B e toda a equipe desembarcou no pátio B. Os maquinistas, que conduziram os trens durante os testes, foram em direção à estação de trem e o técnico e os três engenheiros caminharam na direção contrária, ou seja, em direção ao Pátio A, onde tinham estacionados os carros próprios (Figura 5). 


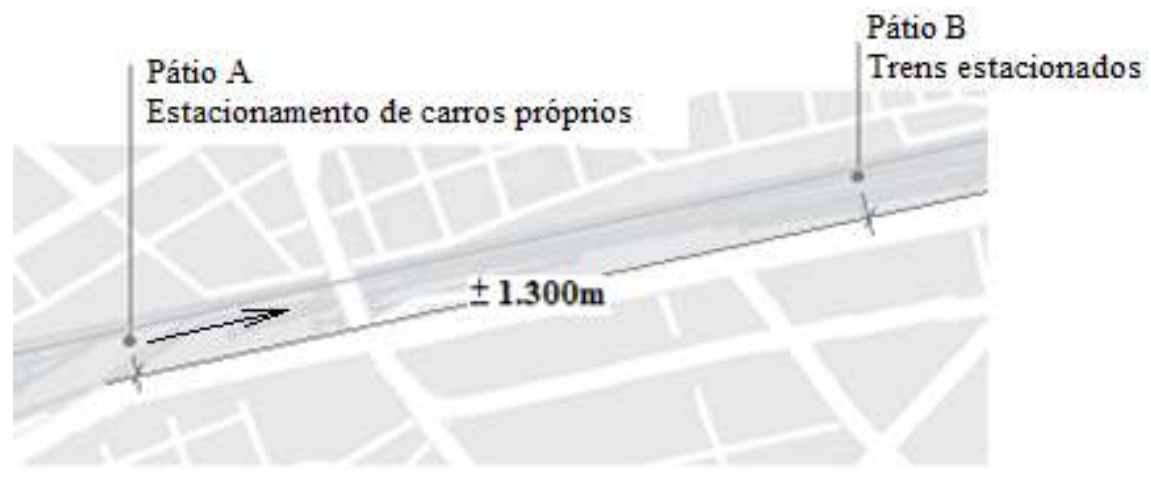

Fig. 4 Representação esquemática da localização do Pátio A e Pátio B Fonte: Adaptado de GoogleMaps - sem escala

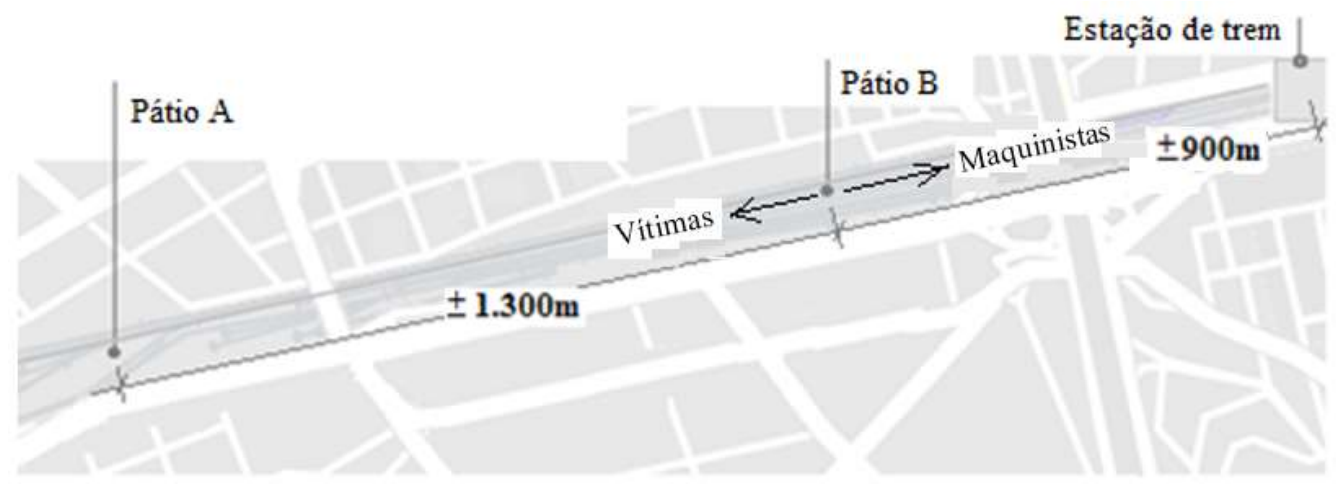

Fig. 5 Representação esquemática do trajeto das vítimas e trajeto dos maquinistas Fonte: Adaptado de GoogleMaps - sem escala

O técnico em manutenção e três engenheiros caminharam na via permanente, do pátio $\mathrm{B}$ em direção ao pátio $\mathrm{A}$, quando um trem em operação com passageiros que trafegava no mesmo sentido, veio de encontro aos trabalhadores pelas costas, às $4 \mathrm{~h} 20$. O técnico e dois engenheiros morreram no local do acidente (Figura 6).

Não há evidências de que o grupo tenha trabalhado junto anteriormente. Nenhuma das vítimas usava colete refletivo, equipamento de proteção individual prescrito pela empresa ferroviária para o uso nesse tipo de deslocamento. 


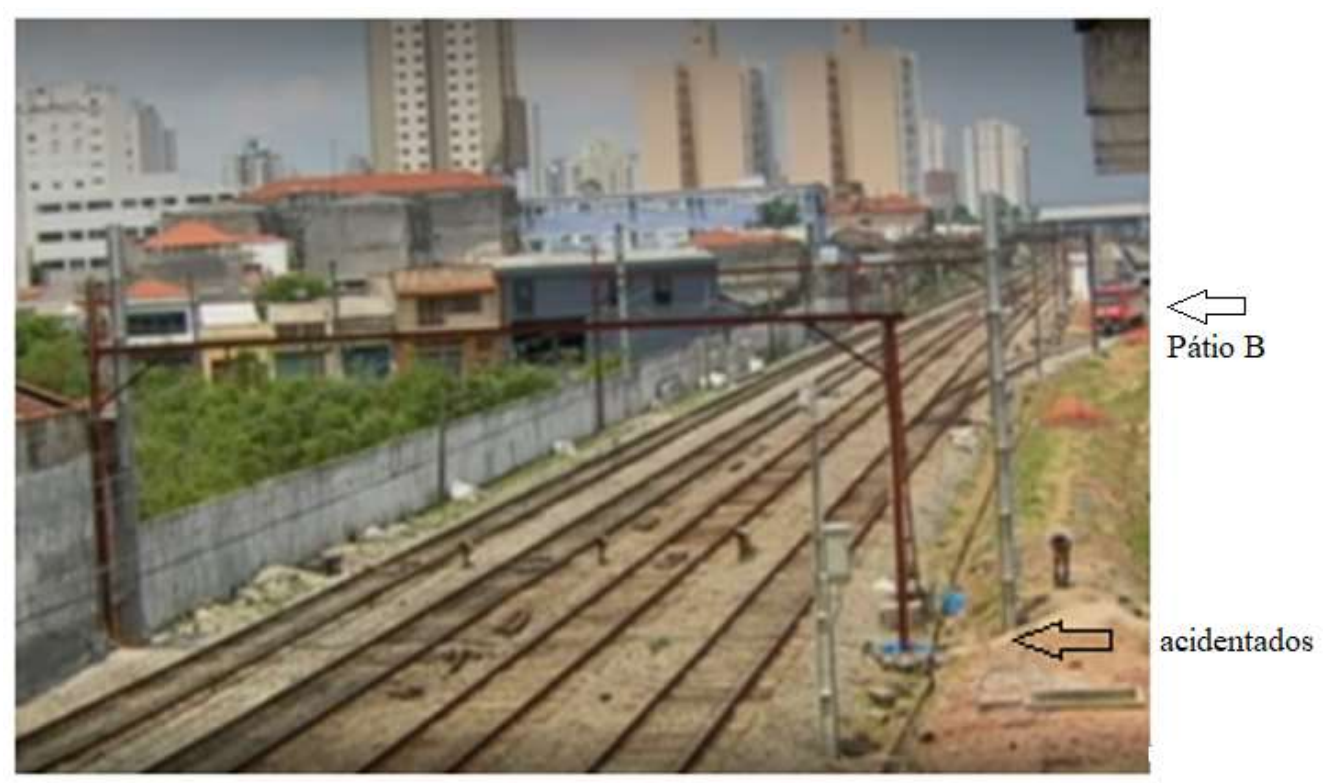

Fig. 6 Foto registrada no dia do acidente Fonte: adaptado de http://tv.r7.com

A sindicância interna da empresa indicou falha humana das vítimas como causa do acidente de trabalho. Ainda segundo o mesmo relatório, o acidente poderia ter sido evitado se os procedimentos operacionais tivessem sido cumpridos. Foi recomendado que os gestores da empresa de transporte ferroviário alertem os funcionários próprios e terceirizados a respeito da obrigatoriedade do atendimento dos procedimentos operacionais e normas de segurança.

\subsection{HISTÓRICO ORGANIZACIONAL}

A empresa de transporte ferroviário metropolitano, onde ocorreu o acidente em estudo, é uma empresa ferroviária criada dezenove anos antes do acidente em estudo, formada a partir da fusão de empresas ferroviárias.

A história das ferrovias, administradas pela empresa em estudo, começa na segunda metade do século XIX quando foi inaugurada ferrovia construída com capital e padrão inglês, segundo relatos dos trabalhadores. Na mesma época, outras ferrovias foram 
construídas na região, com característica americana. Dentre as características, o sentido de tráfego dos trens não adotava o sentido da mão inglesa.

Parte das ferrovias passaram a ser administradas pela empresa A no início da segunda metade do século XX, as quais, por questões de ordem financeira, passaram a ser administradas pela empresa $\mathrm{C}$, anos mais tarde.

Cerca de dez anos depois, a empresa D foi criada e passou a administrar as ferrovias e pouco tempo depois, a empresa D também passou a administrar as ferrovias da empresa B (figura 7).

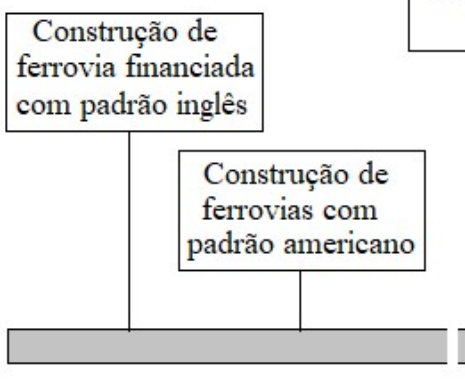

Segunda metade do Século XIX
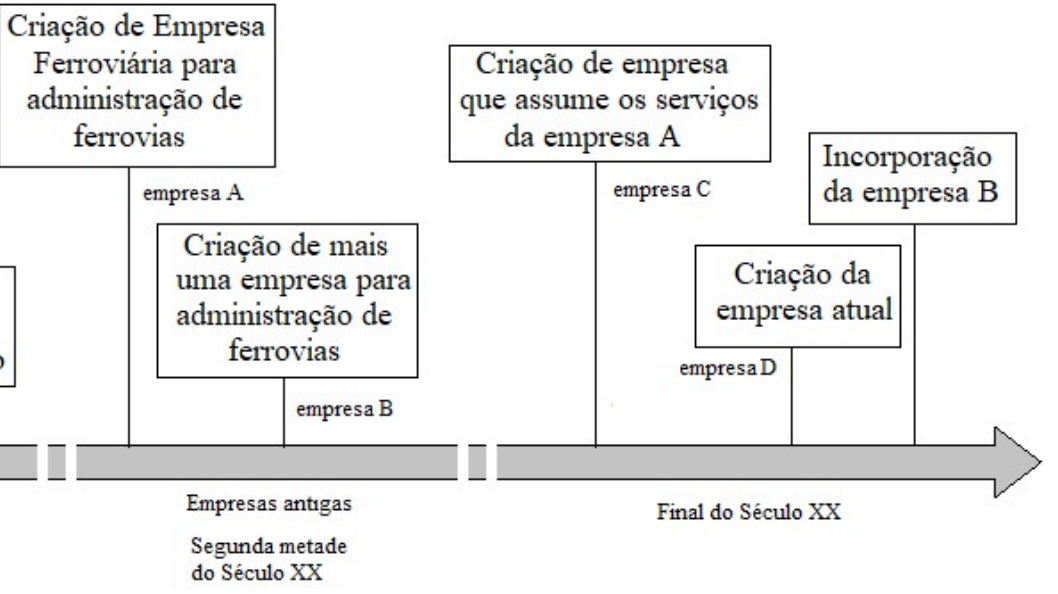

Final do Século XX

Fig. 7 Linha do tempo da evolução histórica da administração das ferrovias Fonte: empresa

A empresa ferroviária atual possui cerca de oito mil funcionários. No decorrer da pesquisa foi possível identificar que cerca de $24 \%$ dos trabalhadores são oriundos das empresas anteriores à fusão, como mostram os dados fornecidos pela empresa (figura 8). Tal fato trouxe consigo a convivência de diferentes formas de compreensão do caráter social do trabalho, com impactos na cooperação entre os múltiplos atores. 


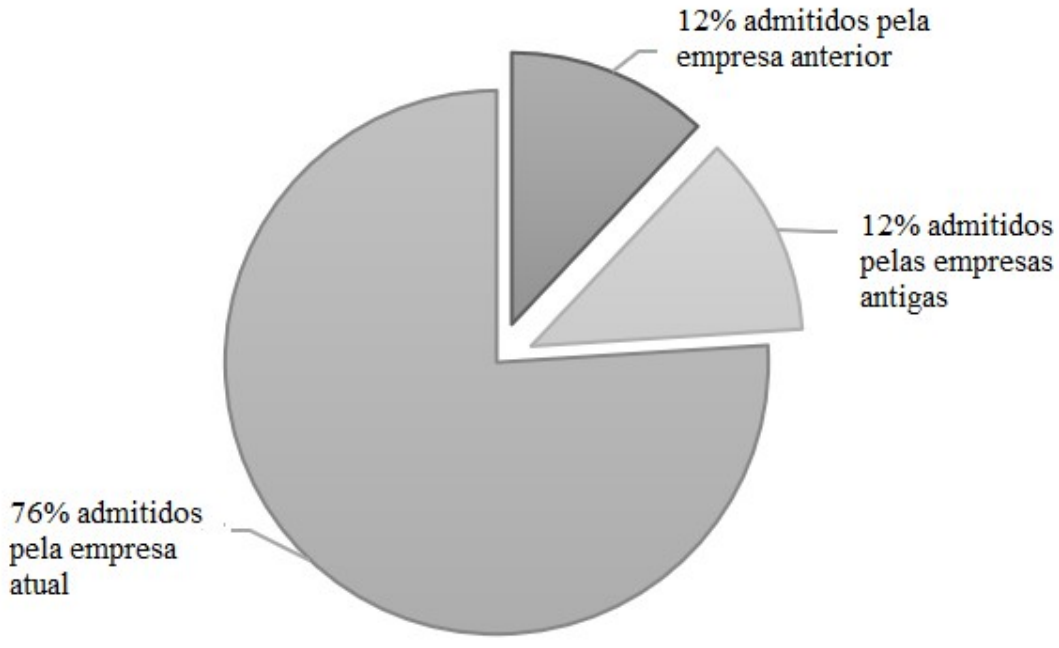

Fig. 8 Origem dos trabalhadores que estão na ativa Fonte: Dados de 2016 fornecidos pela empresa atual

As falas a seguir revelam a visão dos funcionários quanto ao fato de trabalharem com pessoas oriundas de empresas anteriores:

Não temos uma cultura única.

Os novos não conhecem como foi o passado.

É muito difícil trabalhar com o pessoal antigo.

O cara que vem de lá de trás acha que sabe tudo.

Os antigos entraram por indicação, não fizeram concurso.

Geralmente quem tem mais tempo está acomodado. Alguns são mais fechados, não gostam de ensinar.

O uso do computador tem mais ou menos quinze anos na empresa. E há pessoas que se recusam a usar computador.

Dentro do contexto, a forte ruptura na forma de compreender o trabalho entre aqueles trabalhadores que são oriundos das empresas anteriores e trabalhadores oriundos da empresa atual pode impactar nos modos de cooperação intra e inter organizacionais. Sem perceber que o resultado da atividade que estão desenvolvendo tem caráter social, ou seja, só pode ser realizada com a cooperação dos vários atores envolvidos.

Em um ambiente organizacional que não favoreça a cooperação entre as pessoas, quando um grupo de pessoas desenvolve um trabalho juntas, sem que haja elemento de 
identidade que una as pessoas, elas não trabalham como equipe, elas são apenas um grupo de pessoas (VERGANA, 2012).

O modo de cooperação entre o corpo gerencial, operadores de campo e operadores de controle gera impactos diretos na segurança dos trabalhadores (LLORY e MONTMAYEUL, 2010).

Ao longo dos anos, cresceu o número de passageiros que utilizam os trens metropolitanos operados pela empresa em estudo. Alguns eventos contribuíram com o resultado, tais como:

a) Nove anos antes do acidente foi inaugurada nova linha do metrô, que permitiu a integração com uma das linhas de trens metropolitanos. (SEGUNDO... 2011)

b) Seis anos antes do acidente, uma linha do metrô e uma linha de trens metropolitanos passaram a aceitar o bilhete que permite o pagamento de tarifa única para o passageiro que utiliza ônibus, trem ou metrô, dois deles ou três deles no decorrer da viagem. Gradativamente as demais linhas passaram a aderir ao sistema (BALAGO, 2014).

c) E no ano do acidente, mais uma linha de metrô foi inaugurada, passando a integrar com uma linha de trens metropolitanos (INTEGRAÇÃO..., 2011).

Com a integração das linhas dos trens metropolitanos à novas linhas de metrô e o advento da tarifa única para o usuário que utilize de forma integrada os modais, houve um aumento significativo no número de usuários e os trens passaram a ser mais utilizados pela população. Como mostra a figura 9, o período que antecede dez anos do acidente em estudo, houve aumento de $224 \%$ no número de usuários das linhas de trens. 


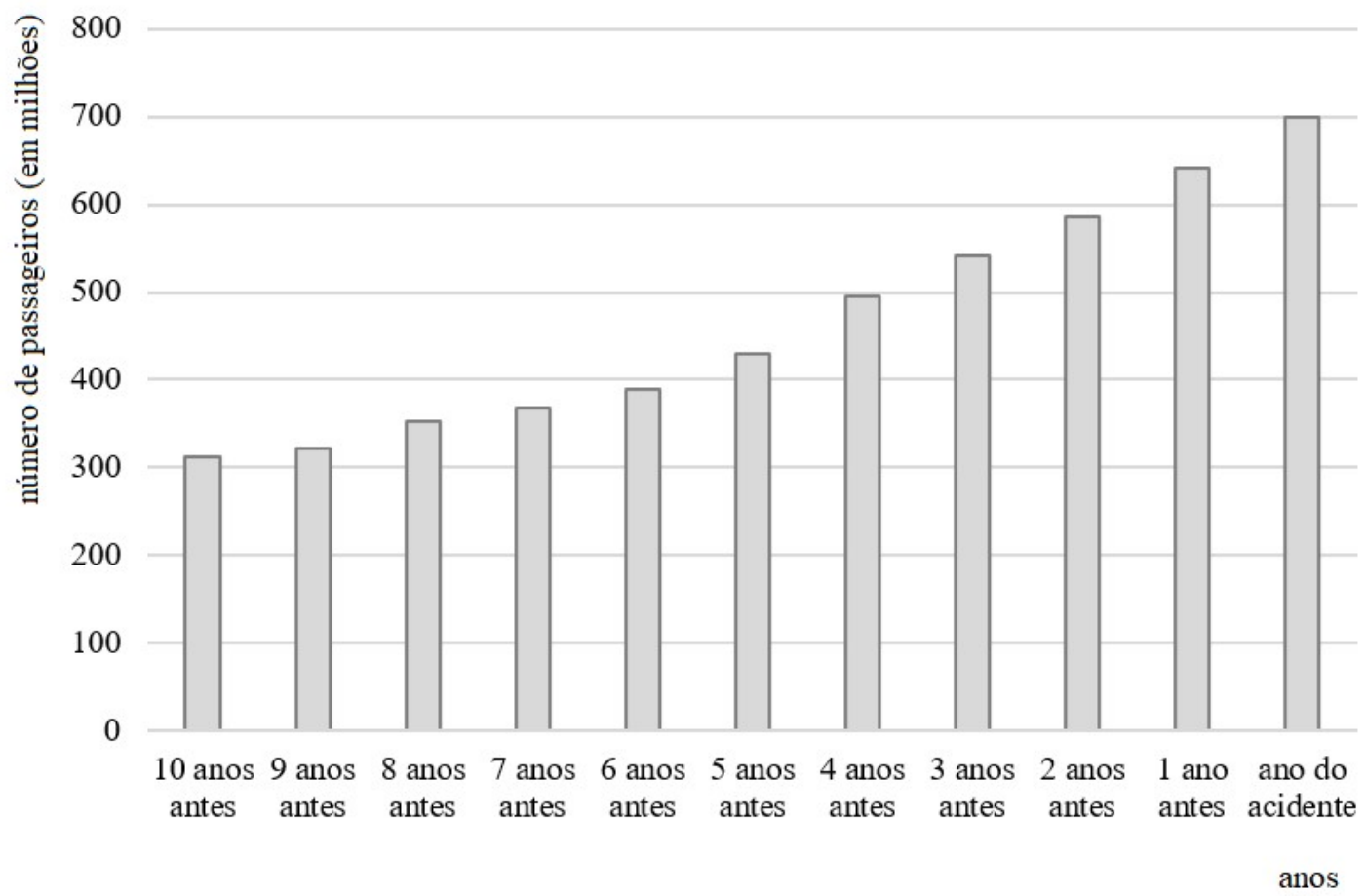

Fig. 9 Número de passageiros que utilizaram os trens metropolitanos por ano (em milhões) Fonte: Dados fornecidos pela empresa atual

Dentro da análise histórica da organização, foi identificado que o período que antecede o acidente de trabalho em estudo apresenta três acidentes envolvendo colisão entre trens e o período imediatamente posterior ao acidente de trabalho em estudo, apresenta dois acidentes envolvendo colisão com trens (figura 10).

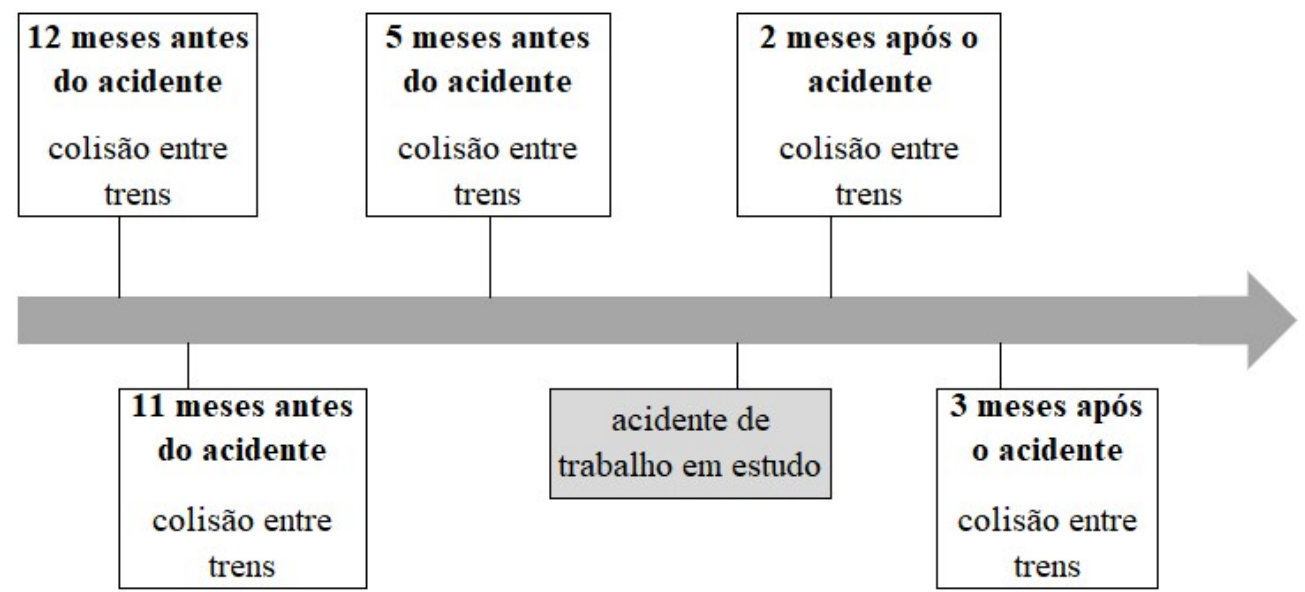

Fig. 10 Linha do tempo das colisões entre trens Fonte: a autora 
a) Doze meses antes do acidente, trens colidiram durante manobra operacional por volta das $2 \mathrm{~h}$ da manhã. A colisão não deixou feridos. (TRENS...2010).

b) Onze meses antes do acidente, por volta das 7h15, houve colisão entre trens nas proximidades de uma estação onde passam duas linhas de trens (COLISÃO...2011)

c) Cinco meses antes do acidente, por volta das $13 \mathrm{~h} 30$, um trem colidiu com outro trem que estava parado à frente, aguardando a sinalização para seguir viagem. $\mathrm{O}$ acidente ocorreu em estação de trem onde passam três linhas de trens. (LINHA...2011). O acidente deixou quarenta e duas pessoas feridas. (GOLSALVES e SPIGLIATTI, 2011)

d) Dois meses após o acidente, por volta das $21 \mathrm{~h}$, um trem colidiu na lateral de outro trem que realizava manobra para transpor a via. $\mathrm{O}$ acidente deixou quatro feridos (COLISÃO... 2012).

e) Três meses após o acidente em estudo, um trem de serviço de manutenção colidiu na traseira de um trem de passageiros, por volta das $8 \mathrm{~h} 50$, deixando mais de trinta e oito pessoas feridas. Na ocasião foi apontada falha humana por haver indícios de que o Centro de Controle Operacional tenha autorizado um dos trens a entrar no trecho onde ocorreu o acidente (FALHA...2012).

Diante do cenário apresentado é possível perceber fragilidade nas eventuais barreiras para evitar colisão.

Além da ocorrência de colisões entre trens, o histórico recente da empresa também apresenta casos de atropelamentos de trabalhadores próprios e terceiros. A contratação de empresas terceirizadas é uma prática comum, de acordo com relatos dos trabalhadores. Tal prática trouxe consigo o seguinte histórico de acidentes de trabalho:

a) Dois anos e um mês antes do acidente, por volta das $19 \mathrm{~h}$, um vigilante que trabalhava em empresa terceirizada morreu após ser atropelado por trem.

b) Dois anos antes do acidente, por volta das $21 \mathrm{~h}$, outro vigilante que trabalhava em empresa terceirizada morreu após ser atingido por trem. 
c) Um ano e cinco meses antes do acidente, por volta das $11 \mathrm{~h}$, um servente de obra sobreviveu após ser atingido por trem.

d) Oito meses antes do acidente, por volta das $22 \mathrm{~h} 30 \mathrm{~min}$, um vigilante morreu após ser atropelado.

e) Dois anos e seis meses após o acidente em estudo, por volta das $2 \mathrm{~h} 50 \mathrm{da}$ manhã, após conclusão de serviço de substituição de trilho e enquanto realizava recolhimento de material entre vias, o supervisor de manutenção morreu após ser atingido por veículo ferroviário tipo caminhão de linha com munk, utilizado para içar materiais e equipamentos. De acordo com o relatório de sindicância realizado pela empresa de transporte ferroviário, o veículo ferroviário, conduzido por trabalhador de empresa terceira, estava com velocidade supostamente acima do permitido, não havia um trabalhador dotado de rádio para orientar o percurso, o farol do veículo ferroviário estava apagado e não foi acionada buzina como sinal de alerta. Por fim, o relatório conclui que operador da empresa terceirizada conduziu o veículo ferroviário de maneira negligente.

Além do último acidente citado acima, acidentes do trabalho envolvendo trabalhadores do setor de manutenção da empresa ferroviária em estudo também surgem no histórico mais recente, reforçando que os trabalhadores do setor de manutenção estão expostos ao perigo de serem atropelados, além dos trabalhadores de empresas terceirizadas:

a) Dois anos e três meses antes do acidente de trabalho em estudo, o encarregado de manutenção da empresa de transporte ferroviário morreu ao ser atropelado por um trem, após realizar verificação de trilho partilho. $\mathrm{Na}$ ocasião foi apurado que o acidente ocorreu por volta das $7 \mathrm{~h} 50 \mathrm{~min}$, havia neblina e o trem estava a aproximadamente $45 \mathrm{~km} / \mathrm{h}$. Apesar do maquinista ter avistado o trabalhador, que estava usando colete, não foi possível evitar o atropelamento. De acordo com o Relatório de Investigação de Acidente de Trabalho emitido pela empresa, houve descuido na observação do ambiente e, como medida preventiva, foi 
definido que os trabalhadores precisam ser instruídos para não caminharem na via e não entrarem na via sem acompanhamento.

b) Um ano e três meses antes do acidente, por volta das $8 \mathrm{~h} 15 \mathrm{~min}$, ao realizar calçamento próximo ao trilho, o técnico em manutenção sobreviveu após ser atingido na região lombar por trem. De acordo com o relatório de investigação do acidente, a vítima sobreviveu ao acidente e o ruído proveniente do equipamento que o acidentado estava utilizando o impediu de ouvir a buzina do trem, bem como, não havia dispositivo de comunicação adequado para alertar o trabalhador na via.

c) Uma semana após o acidente de trabalho em estudo, por volta das $10 \mathrm{~h}$ da manhã, dois assistentes de manutenção, que estavam realizando inspeção na via, morreram após serem atingidos por trem que estava sendo recolhido para o pátio. De acordo com o relatório de investigação, havia solicitação de acesso para realização da atividade de inspeção na via, além dos trabalhadores estarem utilizando capacetes e coletes refletivos. Também foi recomendada intensificação de treinamentos e diálogos de segurança.

Diante do cenário apresentado (figura 11) é possível perceber fragilidade nas barreiras para evitar atropelamentos de trabalhadores, principalmente os trabalhadores oriundos de empresas terceirizadas e trabalhadores do setor de manutenção que vivem o desafio de desenvolver suas tarefas em ambiente operacional dos trens.

Nos vinte e sete meses que antecederam o acidente de trabalho em estudo foram registrados seis atropelamentos e três colisões entre trens. Tais ocorrências não serviram de alerta quanto à urgência na implantação de novas medidas de proteção. 


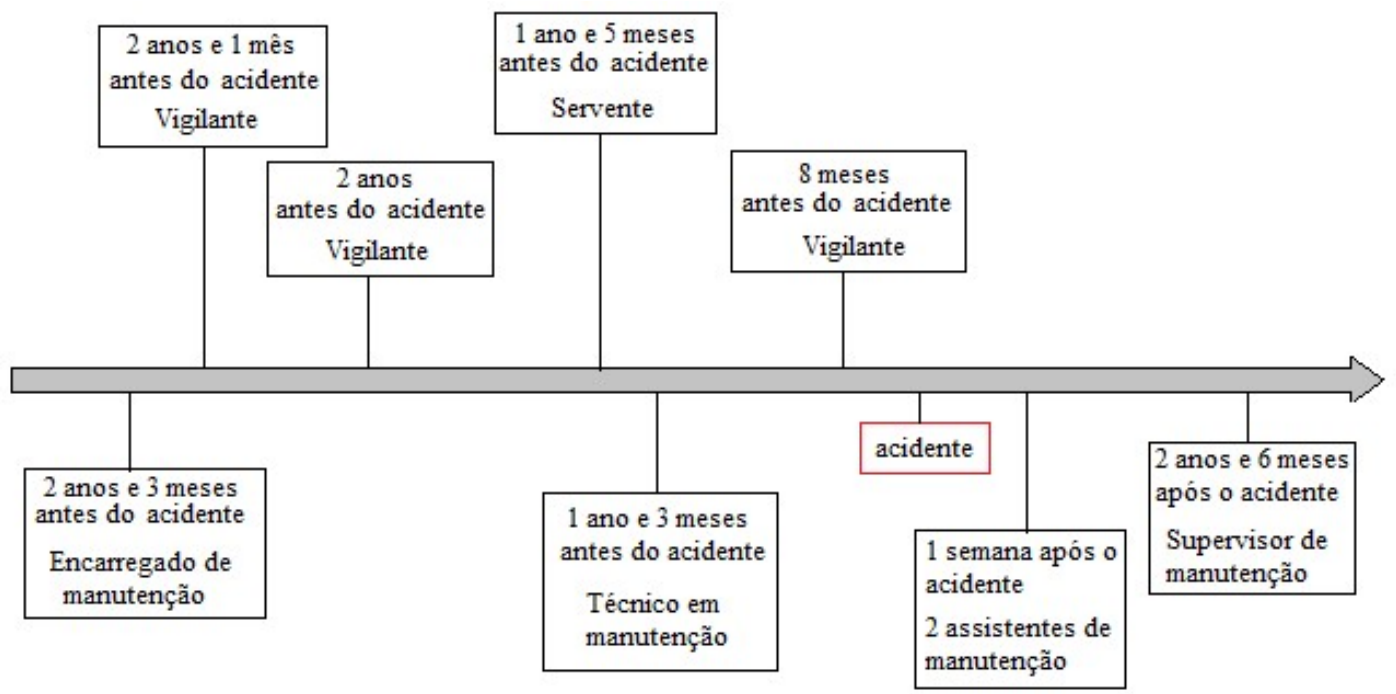

Fig. 11 Linha do tempo das colisões ocorridas antes do acidente em estudo Fonte: a autora

Além de herdar parte da força de trabalho, a empresa de transporte ferroviário também herdou os trens que estavam em circulação, incluindo parte da frota fabricada há mais de quarenta anos antes do acidente em estudo.

Diante do cenário de crescente demanda de usuários e trens velhos em condições precárias, deu-se início o processo de substituição da frota de trens, por meio de licitações que tinham como objeto desde a reforma de trens, aquisição de novos trens e manutenção de trens.

A época do acidente de trabalho em estudo está contida em período de intensa expansão do processo de modernização dos trens. De acordo com os dados fornecidos pela empresa, foram entregues trinta e um novos trens no ano que ocorreu o acidente de trabalho em estudo.

De uma maneira geral, o histórico apresentado reforça a importância do tema análise de acidentes do trabalho sob o ponto de vista organizacional, como instrumento de melhoria dos processos de produção e segurança dos trabalhadores. 


\subsection{O CONTEXTO DA ATIVIDADE DESENVOLVIDA NO DIA DO ACIDENTE DE TRABALHO}

O contrato para fornecimento dos trens que estavam sendo testados no dia do acidente foi celebrado um ano e sete meses antes do acidente entre a empresa de transporte ferroviário e o consórcio de empresas fornecedoras. Tal contrato previa a manutenção de trens e o fornecimento de trinta e seis novos trens com oito carros cada, com a primeira entrega prevista para três meses após o dia acidente.

Durante entrevista realizada na empresa foi relatado que, em linhas gerais, o processo de aquisição e aceitação de trens envolve diversas etapas:

O desenvolvimento do projeto do trem parte da especificação elaborada pela empresa (empresa de transporte ferroviário em estudo). É aberta concorrência pública internacional, por preço e técnica.

O acompanhamento da fabricação é da empresa (empresa de transporte ferroviário em estudo) e por uma empresa de fiscalização contratada. $\mathrm{O}$ primeiro trem fabricado no contrato é acompanhado pela fiscalizadora. Não temos aporte financeiro para deslocamento da equipe, por exemplo, para acompanhar ensaios, é necessário acompanhamento da fiscalizadora.

Durante a fabricação do trem surgem intercorrências, por exemplo, devido à interferência do meio ambiente (calor, poeira....) e intercorrência devido à eletrônica, só começa a perceber quando está no campo. Por isso a especificação está cada vez maior.

Daí surgem os eventos, montagem das caixas onde são realizadas inspeções e ensaios; equipamentos inspecionados e liberação da fabricação; entrega o trem pronto; testes de fábrica; teste dinâmicos (que ocorrem no maior pátio da empresa e onde ficam os escritórios da empresa de transporte ferroviário e da empresa terceira, depois são realizados testes específicos nas linhas. Depois entra em operação assistida, onde o trem trafega na linha sem passageiros, opera em horário de menor movimento e finalmente entra em operação.

O termo de aceite definitivo é emitido somente após o trem percorrer centenas de milhares de quilômetros, para dizer que está bom.

O processo de testes para aceitação dos novos trens passa por testes realizados na fábrica, na via de testes localizado na empresa de transporte ferroviário e testes na ferrovia operacional, antes do trem entrar em operação. E no dia do acidente, o grupo de trabalhadores foi convocado para realizar teste dinâmico em dois novos trens que seriam 
entregues em breve e que faziam parte da primeira entrega do contrato. A tarefa consistia em testar a frenagem nos novos trens, em trecho de ferrovia em rampa, sendo um trem com carregamento de areia para simular o peso dos passageiros e outro sem carga.

A realização dos testes de freios é tarefa eventual. A empresa havia comprado mais de trinta trens novos e recebera os dois primeiros que iriam passar por testes. O teste é condição embutida no contrato e envolve diversos setores próprios da empresa e terceiras, a saber:

a) Equipe de manutenção própria que solicita o teste.

b) Equipe de manutenção própria que irá a campo realizar o teste.

c) Equipe terceirizada contratada para acompanhamento de atividades relacionadas ao contrato, inclusive testes de freios.

d) Equipe própria do Centro de Informações de Manutenção, que solicita autorização junto ao Centro de Controle Operacional devido à necessidade de deslocamentos e isolamentos dos trechos da ferrovia em que será feito o teste.

e) Equipe do Centro de Controle Operacional dos trens, que controla a ferrovia e bloqueia acesso de trens no trecho da ferrovia no horário requerido pela manutenção.

f) Equipe própria da oficina que comunica e providencia o translado dos trens até um dos pátios localizados na ferrovia onde ocorrerá o teste.

g) Equipe de segurança do trabalho que lida com a prevenção de acidentes.

Quanto à segurança do trabalho dos trabalhadores terceirizados, os entrevistados relataram que o Gestor do Contrato é o responsável pela gestão da saúde e segurança dos trabalhadores terceirizados. E para tanto, são exigidos em contrato, o PCMSO, PPRA, CIPA ou designado, a composição do SESMT e Anotação de Responsabilidade Técnica (ART) do engenheiro de segurança do trabalho da empresa terceirizada.

O contrato para fornecimento dos trens que estavam em testes no dia do acidente dispõe que compete à empresa terceirizada: 
a) Primar pelas obrigações no que tange a Segurança do Trabalho, treinamentos e fornecimentos de EPIs.

b) Realizar programas de treinamento de seu pessoal, visando ao constante aperfeiçoamento para adequada exploração da concessão;

c) Obedecer às normas da empresa de transporte ferroviário quanto ao acesso às áreas de serviços em região operacional ou de tráfego de trens;

d) Obrigar que os funcionários estejam devidamente uniformizados com roupas profissionais em bom estado e portando cartões individuais de identificação, bem como EPI's e EPC's necessários à segurança das atividades desenvolvidas. E nos casos de trabalho noturnos estes deverão ser realizados com iluminação adequada e cada funcionário deverá portar, no mínimo, colete refletivo.

Apesar das cláusulas contidas no contrato, não foi evidenciada a realização de análise da compatibilidade do conteúdo elaborado pelas empresas terceiras com modos operatórios utilizados pela empresa em estudo, visto que para realizar os programas de saúde e segurança do trabalho, e demais providências que visam a prevenção de acidentes, requer o conhecimento dos riscos no ambiente de trabalho.

\subsubsection{Programação da Tarefa}

Três dias antes do acidente de trabalho, os novos trens estavam estacionados no Pátio $\mathrm{C}$, junto ao escritório onde o Técnico em Manutenção trabalhava e, como os trens precisariam passar por testes, seria necessário realizar o translado dos trens para o Pátio contido na linha onde os trens seriam testados.

Diante da tarefa que necessitava ser realizada, um funcionário que trabalhava na área de manutenção emitiu um e-mail, na quinta-feira antes do acidente, informando que conforme acordado anteriormente, a programação do translado dos dois trens novos, ou seja, do Pátio C para o Pátio B, seria a partir das $22 \mathrm{~h}$ da sexta-feira. Ainda de acordo com o e-mail, o translado deveria ser realizado na sexta-feira, pois um dos trechos que o trem 
deveria passar estaria interditado no final de semana. $\mathrm{O}$ e-mail finaliza informando que após os testes, os trens deveriam ser recolhidos novamente para o pátio B.

Cerca de trinta e duas horas depois do envio do e-mail e cerca de vinte e oito horas antes do acidente, outro funcionário que trabalhava na área de manutenção emitiu um formulário interno da empresa, que fica disponível em sistema informatizado, para comunicar internamente que os trens sairiam do Pátio A e após os testes deveriam ser estacionados no pátio A. As áreas citadas no formulário de acesso são centro de controle de operações, centro de informação de manutenção, engenharia de manutenção, oficinas e tração operacional.

A linha do tempo representada na figura 12 apresenta, de maneira sucinta, os fatos ocorridos ao longo do tempo.

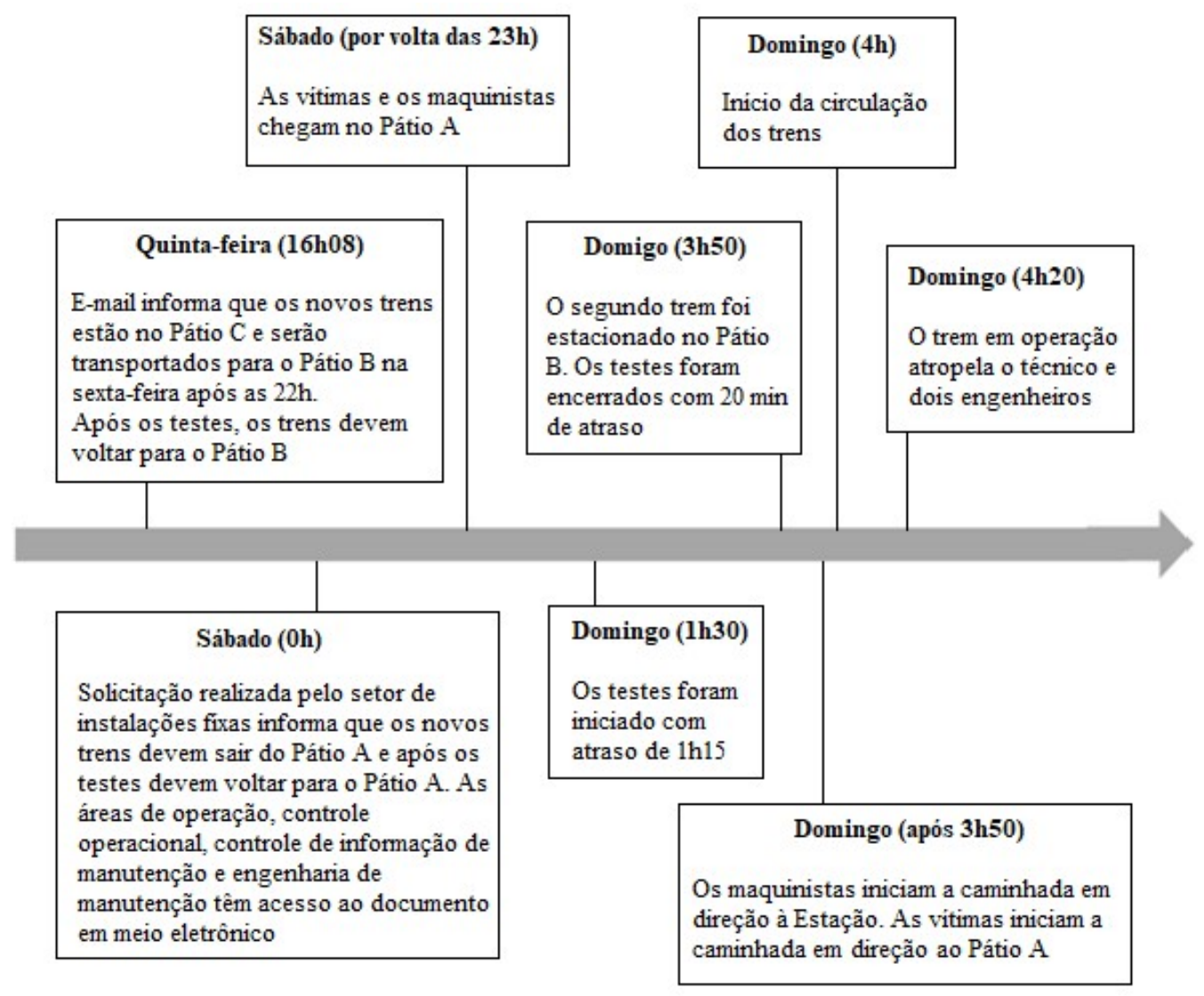

Fig 12 Linha do tempo dos principais fatos que antecederam o acidente Fonte: a autora 
Ao comparar as informações contidas no e-mail com os dados contidos no formulário interno da empresa e com a conversa gravada entre os maquinistas que participaram dos testes e o centro de controle operacional, percebe-se contradição na definição do local onde os trens deveriam estar estacionados e atraso de $1 \mathrm{~h} 15 \mathrm{~min}$ no início do serviço. O atraso no início dos serviços pode estar relacionado ao fato do grupo ter aguardado um trem para levá-los de carona do Pátio A para o Pátio B.

A tarefa, a ser realizada no dia do acidente de trabalho teve como primeira variabilidade a impossibilidade de realização no local originalmente escolhido. Por hipótese, a mudança de pátio pode estar atrelada ao fato do Pátio A não ter espaço para receber os trens em teste, visto que o Pátio A também é utilizado como oficina. Em complemento, segundo relatos dos entrevistados, final de ano pode ter maior demanda de manutenção dos trens devido à época de chuva e ao calor e, por consequência, os Pátios e Oficinas podem estar mais lotados. Além disso, grande parte da frota utilizada pela empresa ferroviária estava no fim da vida útil e estavam em processo de substituição.

Outra hipótese é que o responsável pela emissão do e-mail já sabia que o Pátio A estava lotado, mas quem preencheu o formulário interno indicando que os trens estariam disponíveis no Pátio A desconhecia tal informação. Esta hipótese reforça a importância das empresas terem meios de comunicação eficazes e sem duplicidade.

\subsubsection{O Controle da Movimentação dos Trens na Ferrovia}

A tarefa prevista para o dia do acidente de trabalho estava agendada para ser realizada no intervalo operacional dos trens, que no caso era das 0 h30 até as 4 h da manhã.

O controle da movimentação dos trens na ferrovia é realizado pelos controladores que trabalham no Centro de Controle Operacional (CCO). O local conta com rede que transmite informações de sinalização para os trens e sistema de comunicação via rádio entre maquinistas e controladores. 
O trabalho do controlador que atua no CCO consiste, em linhas gerais, em postos de trabalho específicos para recebimento das comunicações de falha ocorridas nos trens, comunicação da entrada e saída dos trens nos pátios e controle da movimentação dos trens. O controlador interpreta os dados disponíveis em diagramas que representam a movimentação dos trens, consulta dados da programação da operação dos trens, realiza comunicação por rádio com os maquinistas e toma decisões a todo momento, incluindo liberação de rotas para os trens e interdição do tráfego de trens em trechos da via para os serviços de manutenção.

No dia do acidente, os controladores iniciaram a jornada de trabalho às $22 \mathrm{~h}$ e o acidente de trabalho ocorreu cerca de seis horas e vinte minutos após o início da jornada dos controladores. No decorrer da pesquisa foi possível perceber que o encerramento da operação e início das liberações das equipes para a realização dos trabalhos na via é um momento que requer intensa comunicação por rádio entre o controlador do $\mathrm{CCO}$ com os maquinistas que precisam recolher os trens para o pátio, com os maquinistas que precisam de autorização para entrar na via com veículos ferroviários de manutenção e maquinistas que precisam conduzir os trens que serão testados, gerando uma fila de comandos a serem transmitidos rapidamente de forma que não gere atrasos.

Por volta das 3h da manhã foi possível observar, em visitas realizadas na empresa, que os controladores demonstram cansaço, de olhos vermelhos, testa franzida como forma de manter os olhos abertos, além dos bocejos; como estratégia para manter acordados, muitos tomam café a todo momento.

O trabalhador pode desenvolver estratégias para ficar acordado às três horas da manhã. Entretanto, nenhuma instrução vai possibilitar que no decorrer da noite o trabalhador disponha de raciocínio nas mesmas condições de quem trabalha durante o dia, pois as propriedades humanas não são modificáveis (DANIELLOU et al. 2010)

As falas a seguir revelam a visão dos trabalhadores sobre o desenvolvimento dos trabalhos na madrugada:

O nosso trabalho é muito estressante.

Tenho que ter atenção constante. Se houver algum erro, serei punido. 
Entre três e três e pouco da manhã é o horário que pega. Você vai ver, é geral.

Já coloquei na minha cabeça que tenho que dormir oito horas durante o dia, com barulho ou não.

Tenho que dormir de dia, apesar do vizinho estar com reformas.

Não é fácil conciliar o horário de trabalho com a vida pessoal. De dia posso ficar com meus filhos.

Diante da proximidade do início do horário operacional dos trens e do risco de atropelamento, não foi possível constatar evidências de cooperação, entre maquinista que conduzia o trem e controladores que estavam no $\mathrm{CCO}$, no alerta de início do horário operacional e do trajeto mais seguro para os trabalhadores saírem do Pátio B. Por hipótese, o fato do acidente ter ocorrido após $6 \mathrm{~h}$ do início da jornada, associado ao cansaço do trabalho durante a madrugada, pode ter contribuído com a falta de agilidade na identificação e aviso do perigo.

\subsubsection{O Trabalho do Maquinista que Conduzia o Trem Envolvido no Acidente}

O maquinista que conduzia o trem envolvido no acidente tinha 45 anos no dia do acidente, exercia o cargo de maquinista há dois anos. De acordo com formulário próprio da empresa, ele participou de programa de integração que consistiu em parte teórica com duração de 8 horas, fundamentos de primeiros socorros com 4 horas teóricas e 4 horas práticas, além de treinamento prático de formação de maquinista com 208 horas teóricas e 360 horas práticas em modelo de trem que estava em operação a onze anos.

Três meses antes do acidente, o maquinista que conduzia o trem envolvido no acidente participou de treinamento com 8 horas teóricas e 32 horas práticas, no modelo de trem envolvido no acidente e que entrou em operação no ano anterior ao acidente em estudo. Entretanto, não há evidências das tratativas dadas nos treinamentos quanto às barreiras que precisam ser adotadas para evitar atropelamento de trabalhadores, bem como não há evidências de que tal maquinista conduziu o modelo de trem no decorrer dos três meses que antecederam o acidente. 
Um ano após o acidente de trabalho em estudo a empresa modificou o sistema de treinamento disponibilizado para os maquinistas. Desde então, a empresa dispõe de equipamento simulador de trem (figura 13) que é utilizado no treinamento de novos maquinistas aprovados em concurso público.

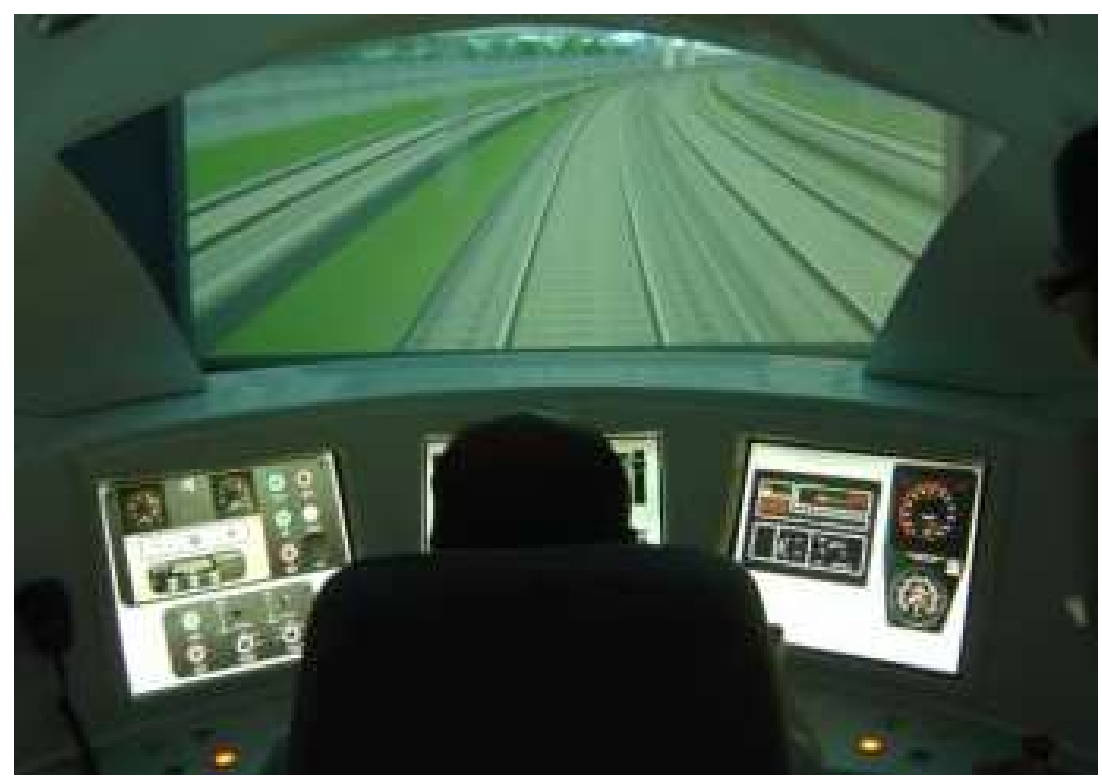

Fig. 13 Equipamento simulador de trem Fonte: Fornecida pela empresa

No decorrer da pesquisa foi possível observar que o equipamento simulador permite simular a ocorrência de neblina, sol, chuva durante a condução do trem e simulação de obstáculos na via para rápido acionamento dos freios. Este ponto é considerado um avanço na qualidade do treinamento, segundo entrevistado.

Ainda segundo funcionários da empresa, o equipamento simulador também é utilizado em treinamentos destinados à reciclagem de conhecimento dos maquinistas admitidos anteriormente, especialmente quando há mudança no tipo de trem que o maquinista irá conduzir. Além de treinamentos no retorno de trabalhadores que ficaram afastados do trabalho por mais de 90 dias.

Em relação ao trabalho realizado pelo maquinista na ocasião do acidente em estudo, a jornada de trabalho foi iniciada às $21 \mathrm{~h} 30$ do dia anterior ao acidente, ou seja, o acidente ocorreu quase 7 horas após o início da jornada. No início da jornada, ele realizou 
viagem de ida e volta com trem, posteriormente ficou à disposição da empresa na estação e por fim iniciou nova viagem às $4 \mathrm{~h}$ da manhã.

De acordo com as imagens gravadas no interior da cabine do trem, após quase sete horas do início da jornada de trabalho, com o trem parado na estação que antecede o local do acidente, o maquinista espreguiça, boceja e na sequência utiliza o rádio acoplado ao painel do trem. Nesse ponto, o depoimento do maquinista aponta que o trem permaneceu na plataforma com as portas abertas até o controlador do centro de controle operacional autorizar por rádio o fechamento das portas e a continuidade da viagem do trem.

Ainda segundo depoimento do maquinista que conduzia o trem envolvido no acidente, o trem estava sendo conduzido na velocidade de $90 \mathrm{~km} / \mathrm{h}$ e com farol ligado no momento do acidente. Ele afirmou que conseguiu avistar as vítimas cerca de trinta metros antes do encontro do trem com as vítimas, acionou a buzina e o freio de emergência, mas o trem parou por completo cerca de cento e cinquenta metros após a colisão.

Perguntado sobre as ações tomadas pela empresa de transporte ferroviário em relação aos trabalhadores próprios que presenciaram acidentes do trabalho, foi relatado que:

Todos os funcionários envolvidos com ocorrência ferroviária passam por avaliação psicológica, por exemplo, o maquinista que conduz o trem que atropelou.

O INSS pediu em 1999 para a empresa incluir atropelamento como doença ocupacional. Aí abrimos CAT (Comunicação de Acidente dee Trabalho) por estresse pós-traumático.

No caso dos maquinistas que presenciam o acidente, a falha ou falta de barreiras que deveriam ter mantido sob controle o perigo de atropelamento, gera estresse póstraumático. Tal fato reforça a importância de ações voltadas para a implantação de efetivas barreiras de proteção.

Questionado a respeito das dificuldades encontradas na organização do trabalho, foi apontado que o absentismo, por parte dos maquinistas, é crítico na área. Além de representar mais uma variabilidade do ponto de vista da gestão da jornada dos trabalhadores, o absentismo pode ter alguma correlação com os fatores psicológicos do 
trabalho. Nesse ponto, trabalhadores que já exerceram o cargo de maquinista relataram o sofrimento vivido decorrente do atropelamento de transeuntes e colegas de trabalho.

4.3.4 O Trabalho dos Maquinistas que Trabalharam nos Testes no Dia do Acidente

No dia do acidente de trabalho em estudo quatro maquinistas trabalharam nos testes. Cada dupla de maquinistas ficou encarregado de pilotar o novo trem desde a saída do Pátio até o retorno do trem para o Pátio.

Por volta das $23 \mathrm{~h}$ do dia anterior ao dia do acidente, os maquinistas se encontraram com o Técnico em Manutenção e os Engenheiros no Pátio A. Na sequência, aguardaram o Técnico em Manutenção providenciar um trem que iria levá-los de carona do Pátio A para o Pátio B.

Toda a conversa realizada entre os maquinistas dos novos trens e o controlador do CCO por meio do rádio acoplado ao painel do trem, foram gravadas.

Após a realização dos testes, os maquinistas do primeiro trem que chegou no Pátio B aguardaram a chegada do segundo trem onde estavam mais dois maquinistas, o técnico e os engenheiros. Em depoimento, um dos maquinistas informou que não conversou com o técnico sobre os meios para sair do Pátio $B$, enquanto outro maquinista alega que o técnico afirmou que preferia ir à pé para o Pátio A.

Os quatro maquinistas caminharam juntos no sentido oposto ao que foi seguido pelos engenheiros e pelo técnico. Não há evidências que os maquinistas alertaram sobre os riscos de caminhar sobre os trilhos.

De acordo com o depoimento de um dos maquinistas, no caminho para a estação de trem (figura 14) provavelmente o depoente e os demais maquinistas cruzaram com o trem que atropelou as vítimas, mas não se lembra desse fato. 


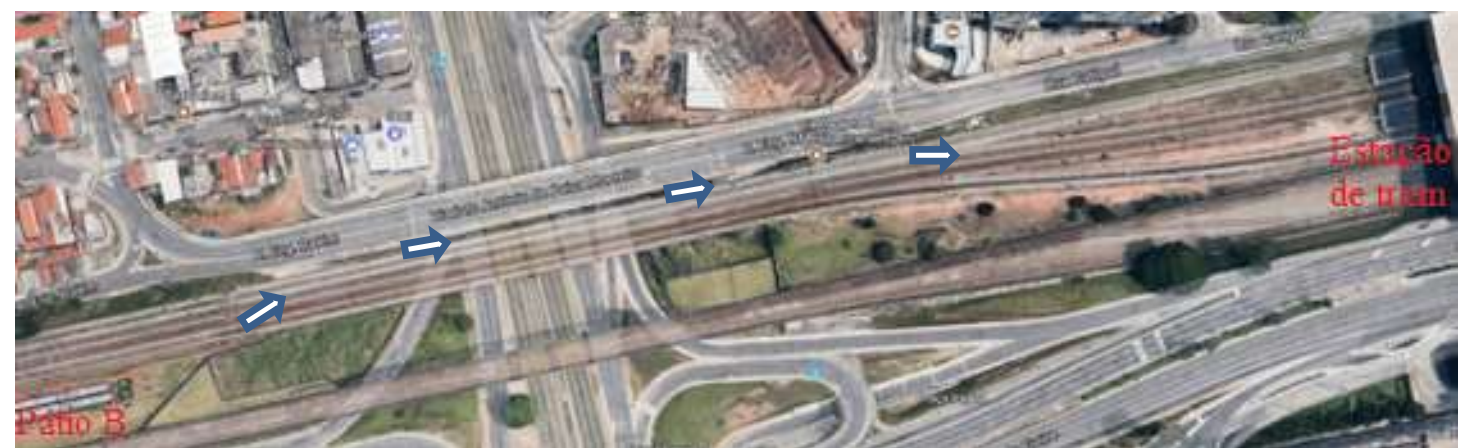

Fig. 14 Localização do trajeto do Pátio B até a Estação de trem mais próxima Fonte: Adaptado de GoogleMaps

Apesar dos depoimentos realizados pelos maquinistas informarem que os mesmos iriam caminhar no sentido da estação de trem, a gravação em vídeo, realizada na cabine do trem em operação, não evidencia que os maquinistas que participaram dos testes dos novos trens seguiram em direção à passagem de nível que sobrepõe uma grande avenida. Entretanto, foi verificado no local que o trecho da linha férrea sobre uma das principais avenidas da cidade, apresenta distância reduzida entre o trem e o guarda-corpo da via, evidenciando que o trajeto também apresenta riscos (figura 15); além disso requer a travessia da via para acessar a Estação de Trem.

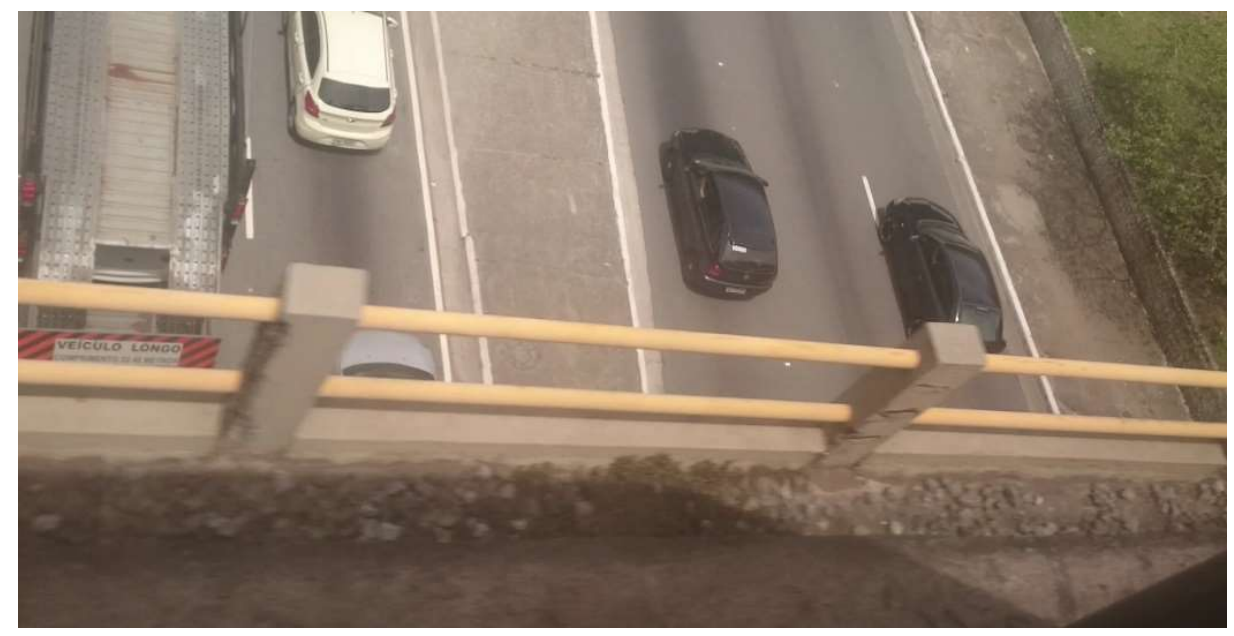

Fig. 15 Imagem de dentro do trem mostra o espaço entre a via onde ocorreu o acidente e o guarda-corpo em trecho sobre avenida.

FONTE: a autora 


\subsubsection{O Trabalho do Técnico em Manutenção}

No acidente de trabalho em estudo, o único trabalhador próprio acidentado é o Técnico em Manutenção. Ele tinha quarenta anos e foi admitido vinte e dois anos antes do acidente, ou seja, foi admitido pela empresa anterior à fusão que deu origem a empresa atual. E estava há quatorze anos no departamento responsável pela manutenção dos trens e gestão de contrato de aquisição de novos trens.

Ao analisar os treinamentos de que o trabalhador participou, percebe-se que ele realizou mil e trinta horas de treinamento ao longo dos quatorze anos em que ele trabalhou na Gerência de Engenharia de Manutenção, sendo que cento e setenta e nove horas foram realizadas no ano do acidente de trabalho. Além de ter conquistado o diploma de graduação em Engenharia Elétrica alguns anos antes do acidente.

Dentre os treinamentos realizados no ano do acidente, apesar de constar treinamento que tratava das instruções relativas ao trabalho, não há evidências de que foram abordados aspectos de segurança do trabalho em tal treinamento.

Ele trabalhava em horário comercial, no escritório localizado junto ao Pátio $\mathrm{C}$ localizado em ferrovia construída no padrão americano, dentro do perímetro da empresa. E não foi identificada evidência de que o técnico tenha realizado testes com a mesma equipe de engenheiros anteriormente.

De acordo com relato dos trabalhadores, eventualmente é necessário que um Técnico em Manutenção realize atividade em Pátio localizado em ferrovia, administrada pela empresa que segue o sentido de movimentação dos trens em sentido inverso, ou seja, com base no padrão inglês.

O trabalho noturno surge como uma atividade eventual, decorrente de testes que precisam ser feitos no período fora do horário de operação dos trens. Sendo assim, quando um trabalhador está na condição de trabalho noturno esporádico, é necessário considerar que o estado de alerta da pessoa não é o mesmo estado de alerta de quando ela trabalha no período diurno, pois o corpo humano possui relógio biológico que faz com que 
fisiologicamente seja impossível manter o estado de atenção pleno na mudança do horário da jornada. A fadiga influencia o estado das pessoas, principalmente quando a duração do trabalho não for habitual. Diante do exposto, o trabalho noturno requer maior número de condições favoráveis do que o trabalho realizado de dia (DANIELLOU et al, 2010).

Diante do cenário, a barreira prevista pela empresa é a comunicação, de início e término do serviço, entre o funcionário da manutenção e os controladores do Centro de Informação da Manutenção (CIM), que é responsável pelo controle, coordenação, acompanhamento dos acessos, manobras elétricas ao longo da via e registro de falhas no sistema.

\subsubsection{O Controle dos Serviços de Manutenção na Via Férrea}

Os trabalhadores do setor de Controle de Informação da Manutenção (CIM), atuam em uma sala localizada no mesmo espaço físico que os controladores do CCO. Há apenas uma divisória de vidro que separa os dois grupos de trabalhadores. Cada controlador do CIM trabalha oito horas por dia, em uma bancada, chamada de console, onde analisam as telas de computador contidas na bancada e painéis e telefones.

O trabalho do controlador que atua no CIM consiste, em linhas gerais, no monitoramento do início e término das solicitações de acesso dos trabalhadores para realização de trabalhos na via e o recebimento, análise e classificação dos pedidos de abertura de falhas nos trens e vias.

Os trabalhos que requerem acesso de trabalhadores e/ou equipamentos à via férrea são discutidos em reuniões quinzenais, onde são identificados os serviços que precisam ser realizados primeiro, a duração de cada serviço e a data permitida para a realização. Após a reunião é emitida uma Solicitação de Acesso Programado. Contudo, a necessidade de acesso à via nem sempre pode aguardar a reunião e posterior programação. Nestes casos podem ser abertos dois tipos de Solicitações de Acesso: o primeiro tipo é Solicitação de Acesso Extra, quando há a necessidade de realizar um trabalho não 
programado e que será realizado no mínimo após setenta e duas horas da abertura da solicitação de acesso no sistema e o segundo tipo é Solicitação de Acesso Prioritário, que não entrou na programação, mas é considerado que o serviço deve ser impreterivelmente realizado em determinada ocasião.

No caso do acidente em estudo, a Solicitação de Acesso foi do tipo Prioritário. Quando há necessidade de abertura de Solicitação de Acesso Prioritário, um representante do setor que irá realizar o serviço faz o preenchimento do formulário no sistema informatizado da empresa, sem a necessidade de autorização prévia em reunião, pois consideram que se trata da continuação de um trabalho iniciado anteriormente. Após o cadastramento da solicitação no sistema, de acordo com relato dos trabalhadores, o controlador do CIM faz controle de início e término dos serviços.

Em relação aos meios de locomoção dos trabalhadores que realizam atividades de manutenção nas vias da ferrovia ou trens, no momento da realização do serviço, de acordo com o relato dos entrevistados, vão até o local onde ocorrerá o serviço, por meio de veículo ferroviário de manutenção que trafega sobre os trilhos ou vão à pé, caso o local de serviço esteja próximo à estação. Também há opção de ir até o local pelas vias urbanas, com veículo automotivo. Esta última opção requer que os trabalhadores pulem o muro que delimita a área dos trilhos o que acrescenta o risco de queda (figura 16).

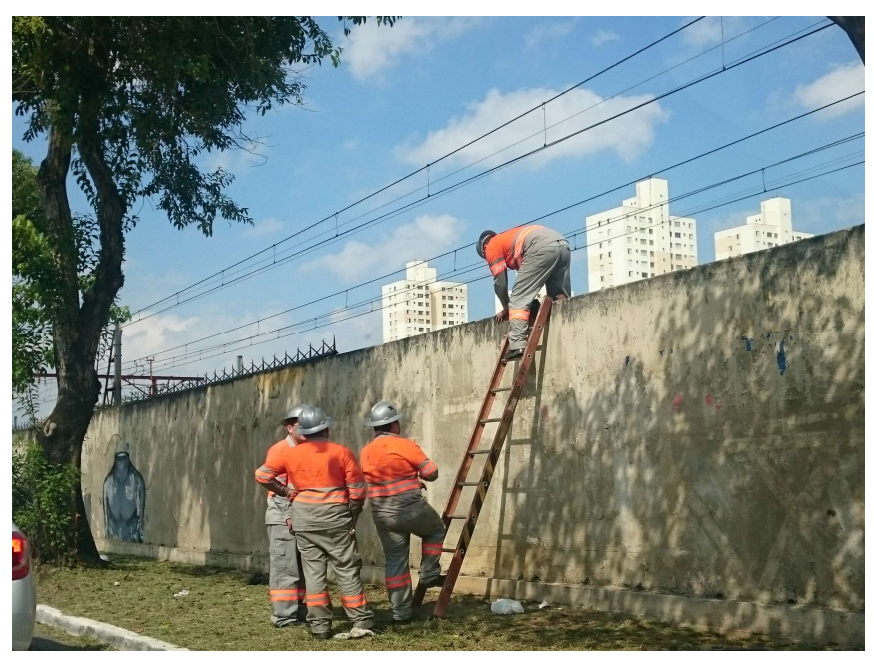

Fig. 16 Trabalhadores acessando a via FONTE: a autora 
Assim que o trabalhador chega ao trecho onde será realizado o serviço, o trabalhador da manutenção entra em contato por telefone com o Controlador do CIM e comunica o número de pessoas que irão trabalhar no local, além de informar que estão disponíveis para realizar o trabalho. O controlador do CIM confirma com o controlador do CCO se a via está liberada para início dos serviços. Ao terminar o serviço, o trabalhador faz contato por telefone com o controlador CIM para informar que concluiu o serviço e, por sua vez, o Controlador do CIM comunica o término do serviço para o Controlador do CCO.

Em complemento, caso o serviço envolva a necessidade do uso de veículo ferroviário de manutenção, o maquinista entra em contato com o controlador do CCO para pedir autorização de entrada na via em operação.

Ao analisar tal sistemática, no caso de serviços que não requeiram veículo ferroviário de manutenção, percebe-se que, a partir do momento da comunicação do término do serviço, não há comunicação da efetiva saída dos trabalhadores da área de risco de atropelamento. Tal fato representa uma fragilidade na proteção dos trabalhadores.

Além do fato dos Controladores do CIM trabalharem na madrugada, assim como os Controladores do $\mathrm{CCO}$, foi relatada a possibilidade dos Controladores do CIM atuarem, eventualmente, por doze horas, no caso do operador do turno seguinte não comparecer ao trabalho acentuando a fadiga o trabalhador.

De acordo com o relato dos trabalhadores, o ritmo intenso de trabalho dos controladores do CIM, com horário de trabalho que varia entre o período noturno e período diurno, são os principais aspectos que levam ao absenteísmo. Como estratégia para lidar com a falta de trabalhadores no setor e com a impossibilidade de rápido preenchimento de vaga de emprego, a empresa admite técnicos recém-formados na escola que a empresa mantém convênio para atuar no CIM.

\subsubsection{O Trabalho dos Engenheiros}


O acidente de trabalho em estudo também vitimou três engenheiros que estavam a serviço de empresa terceirizada, além do técnico em manutenção da empresa de transporte ferroviário.

Um dos engenheiros que morreu no acidente era espanhol, sem família no Brasil e trabalhava para uma empresa de origem alemã (ESPANHOL...2011). Tal empresa é fornecedora de sistemas de frenagem para veículos ferroviários. Ele recebeu treinamento de integração do consórcio de empresas cerca de um mês antes do acidente de trabalho. Não há evidências de entrega de EPIs e orientação quanto às medidas de proteção quanto ao risco de atropelamento. Também não há evidências de trabalhos similares realizados anteriormente nas ferrovias administradas pela empresa em estudo.

Outro engenheiro que morreu no acidente era brasileiro e trabalhava na empresa que fabricou os novos trens. Ele recebeu treinamento de integração da empresa fabricantes dos trens quatro meses antes do acidente. Além disso, a ordem de serviço assinada por ele não indica o risco de atropelamento, evidenciando que o trabalho não previa a necessidade de acesso à via.

O terceiro engenheiro, que sobreviveu ao acidente de trabalho, trabalhava na empresa que fabricou os novos trens. Apesar de não ter sido disponibilizada documentação que evidencie a data da admissão, a sua ficha de EPI não evidencia o fornecimento de colete refletivo, o que reforça que o trabalho desenvolvido pelo engenheiro não requeria a necessidade de caminhar na via. Além disso, ele comenta no depoimento que não recebeu orientação da empresa de transporte ferroviário quanto às suas normas de segurança do trabalho.

Quanto ao local do acidente, segundo relato do sobrevivente, existe a via permanente onde trafegam os trens com passageiros, a via de testes onde são realizados testes em trens em movimento com acesso restrito, com cadeado, e o pátio de trens onde são realizados testes com o trem parado, além da manutenção dos trens. No pátio os trens trafegam a $10 \mathrm{~km} / \mathrm{h}$ e a passagem de pessoas sobre os trilhos requer atenção de todos.

Quanto ao fato dos acidentados terem caminhado na via permanente onde trafegam os trens com passageiros, a testemunha que sobreviveu ao acidente relatou que 
imaginava que após os testes seriam deixados no Pátio A e que só entendeu que estava caminhando na via comercial, após ter visualizado foto aérea do local do acidente.

\subsubsection{Análise do trabalho}

O teste de frenagem de composições novas é tarefa eventual cuja realização envolve diversos setores próprios da empresa e equipes de terceiras, que se encarregam do pedido e agendamento do teste, da mobilização de trabalhadores próprios e terceirizados, das comunicações com o Centro de Informação da Manutenção (CIM), com o setor responsável pela gestão do contrato e o Centro de Controle Operacional (CCO), visando ao deslocamento das composições para local dos testes e bloqueio dos trechos em que serão utilizados.

A tarefa teve como primeira variabilidade a impossibilidade de sua realização no local originalmente escolhido. A equipe de teste só foi informada no chegar no Pátio A.

O transporte de ida até o Pátio B se deu por meio de trens ainda em circulação e, ao final da tarefa não havia transporte para levar os trabalhadores de volta. Quatro dos oito trabalhadores, cujo automóvel estava estacionado no Pátio A, voltaram andando sem coletes refletores pela ferrovia mal iluminada, sendo que a maioria não conhecia que ali se operava na mão inglesa.

Segundo procedimentos da empresa, esse tipo de caminhada deveria ocorrer pela faixa lindeira, que é a área contígua aos trilhos, para evitar atropelamentos. Entretanto, observações realizadas após o acidente constataram que no local há trechos onde essa faixa é muito estreita ou com presença de postes, restos de obra e caixas sem tampa. Deste modo, é praticamente impossível o deslocamento na via sem a exposição ao risco de atropelamento. Os fatos colhidos permitem afirmar que apesar da existência de regra determinando que o trabalhador caminhe na faixa lindeira à $1,80 \mathrm{~m}$ do trilho, qualquer trabalhador que se deslocasse na via o faria como fizeram as vítimas. Nesse sentido, a norma pode então ser descrita como uma ferramenta impraticável para prevenir acidentes. 
Até onde foi possível esclarecer sobre o conteúdo de treinamento de segurança na empresa, não há neles nada que oriente ou estimule o treinando a considerar e a avaliar as decisões que toma para lidar com situações de variabilidades como as identificadas neste acidente.

Dentro do cenário do acidente, quando um trabalhador está na condição de trabalho noturno esporádico é necessário considerar que o seu estado de alerta não é o mesmo de quando trabalha no período diurno, pois o corpo humano possui relógio biológico que faz com que físiologicamente seja impossível manter o estado de atenção pleno na mudança do horário da jornada. A fadiga influencia o estado de alerta das pessoas, principalmente quando a duração do trabalho não for habitual. Na situação do acidente a fadiga e a baixa no estado de vigília podem ter influenciado a percepção dos trabalhadores inclusive no tocante ao fato de que a via onde caminhavam operava na mão inglesa, ensejando falsa ilusão de segurança.

A análise não conseguiu esclarecer como eram histórica e habitualmente as práticas de tomadas de decisão na empresa em situações assemelhadas. É possível considerar que, muito provavelmente, em face desse tipo de situação, os trabalhadores terceirizados tendam a seguir as escolhas adotadas pelos próprios. Além disso, é pertinente considerar que, entre outras coisas, dadas a hora do evento, circunstâncias de final de tarefa nas proximidades do início de circulação de trens, atividade em campo, sem supervisão direta de chefia, lidando com variabilidade não antecipada, a decisão tenha sido influenciada por margem de autonomia dos envolvidos e práticas habitual e historicamente adotadas no sistema.

O condutor da composição que trafegava a cerca de $90 \mathrm{~km} / \mathrm{h}$, com farol aceso e atropelou os trabalhadores afirmou não ter sido informado da presença de colegas na linha e supõe que os enxergou quando estava a cerca de 30m de distância. E que apesar da frenagem eles acabaram atingidos.

No que se refere aos coletes refletivos, foi constatado que os terceiros não haviam recebido tais equipamentos de proteção, bem como o trabalhador próprio havia recebido um colete oito anos antes do acidente, cujo estado de conservação não foi descrito. Além disso, não foi possível esclarecer as razões do não uso do colete por esse trabalhador. É 
possível que razões ligadas ao estado de conservação do equipamento recebido há muitos anos tenham influenciado nesse comportamento. Será que após tantos anos ainda estaria em condições de uso?

O fato da informação inicial indicar que o grupo partiria do Pátio A e que após os testes de frenagem, o grupo estaria de volta no mesmo Pátio A, sem a necessidade de caminhar na via, poderia ter contribuído para que não considerasse necessário levar consigo o colete, mesmo porque, até sua chegada no local indicado, a caminhada pela via não era prevista e o trabalhador poderia agir como se não houvesse indicação técnica de uso do colete. Outros aspectos poderiam ter influenciado nesse comportamento, mas a análise não conseguiu esclarecer como era histórica e habitualmente a adesão, de próprios e de terceiros ao uso do colete e de outros equipamentos de proteção individual.

Em função do atraso, o teste foi finalizado cerca de dez minutos antes do horário de reinício da circulação de trens; além disso, não foram encontrados registros de comunicação das vítimas com o setor de controle operacional ou setor responsável pelas informações de manutenção sobre a volta desses trabalhadores pela via. Também não foram encontradas evidências de que o deslocamento dos trabalhadores naquela via tivesse sido sinalizado, visando alertar maquinistas de trens que circulassem na mesma área e horário.

A análise sugere que as prescrições existentes no tocante a comunicações, como as que seriam necessárias em situações assemelhadas, deixam clara as recomendações a serem adotadas em situação de trabalho em que tudo transcorre de acordo com a normalidade planejada. Mas elas não especificam de modo claro a quem caberia fazer o quê, com que meios, naquele horário, em face de variabilidades como as ocorridas no dia do acidente.

Neste caso, houve preocupação de explorar evidências de contribuições de evolução assíncrona do sistema para o acidente. Até que ponto mudanças relacionadas ao processo de modernização de setores da empresa criaram dissintonias ou dificuldades nas interações entre esse setor e os demais setores? Por exemplo, os meios de comunicação mais ágeis e mais confiáveis, ou ainda os sistemas de sensores de presença, os meios adotados pelo setor de controle operacional de trens nas interações com equipamentos 
instalados nos Pátios A e B e disponíveis para o grupo de trabalhadores acidentados: eram já plenamente compatíveis ou não? Por volta das $4 \mathrm{~h}$ da manhã ofereciam as melhores e mais ágeis alternativas de comunicação para integrantes do grupo de trabalhadores que realizava o teste de freios das composições? Esses aspectos não foram respondidos, em grande parte por dificuldade de acesso da equipe de análise aos profissionais da empresa que soubessem e se dispusessem a respondê-las.

Em síntese, os aspectos descritos indicam que nas origens do acidente analisado há elementos de falhas como mostra o quadro 2.

Quadro 2 - Descrição da atividade habitual

\begin{tabular}{|l|}
\hline Descrição da atividade habitual: Teste de frenagem e novos trens \\
\hline Tarefa eventual cuja realização envolve setores próprios da empresa e equipes de terceiras. \\
A tarefa inclui programação com agendamento, mobilização de equipes de manutenção própria e \\
terceirizada, comunicações com centros de informação e de controle de operações, inclusive após o final \\
dos testes, transporte dos trens para locais de testes, etc. \\
O acidente ainda envolve interação com a atividade de condução do trem que atropelou as vítimas. \\
Destacam-se equipes de manutenção que solicitam o teste, equipe que vai a campo, equipe terceirizada, \\
setor responsável pela informação de manutenção, setor responsável pelo controle operacional dos trens, \\
equipe que providencia o translado do trem e equipe de segurança. \\
A tarefa teve como primeira variabilidade mudança do local (Pátio A) originalmente escolhido, que só \\
foi informado à equipe de manutenção quando esta chegou lá. \\
Essa mudança fez com que a equipe precisasse se deslocar até o novo local. \\
O acidente aconteceu quando parte dos trabalhadores voltava para o Pátio A, sem coletes refletivo, \\
andando pela via férrea mal iluminada, não conhecida e que operava em mão inglesa. \\
A faixa lindeira onde os trabalhadores deveriam caminhar é muito estreita, carregada de sujeira e \\
obstáculos. \\
A análise não conseguiu esclarecer como eram histórica e habitualmente as práticas de tomadas de \\
decisão na empresa em situações assemelhadas. \\
O condutor da composição que atropelou os trabalhadores afirmou não ter sido informado da presença \\
de colegas na linha e que os enxergou quando estava a cerca de 30 m de distância. E que apesar da \\
frenagem eles acabaram atingidos. \\
Os aspectos descritos indicam que nas origens do acidente analisado há elementos de falhas de gestão \\
da atividade, inclusive em seu planejamento, falhas na organização e condições de trabalho, falhas em \\
gestão de comunicações necessárias à coordenação de interações entre tarefas, falhas na gestão de \\
manutenção e na gestão de contratos de terceiras. \\
\hline
\end{tabular}




\subsection{ANÁLISE DE BARREIRAS}

No âmbito do planejamento da tarefa não há evidência da realização de análise de perigos e riscos de tarefas quando o trabalhador desenvolve tarefa na via férrea. Segundo relato, tal análise só é conduzida quando há serviços que envolvam energia elétrica.

No âmbito do trabalho realizado pelo trabalhador próprio, a ordem de serviço de segurança para os trabalhadores do departamento a que o Técnico em Manutenção pertencia, descreve que os riscos ocupacionais são choque elétrico, queimadura, queda por diferença de nível e no mesmo nível, escoriações nos membros superiores ao manusear equipamentos e ferramentas, perda auditiva, inalação de poeira, vapores e gases, e por fim, atropelamento pela circulação de trens nos pátios ou vias férreas.

As medidas de proteção incluem não fumar, utilizar ferramentas em condição de uso, utilizar equipamentos e ferramentas elétricas isoladas e utilizar os EPIs indicados pela segurança do trabalho. Além disso, os trabalhadores devem obedecer à sinalização de segurança e recomendações do encarregado, obedecer às orientações contidas nos procedimentos e paralisar a atividade imediatamente quando houver risco de acidente ou dúvidas em relação à segurança. Entretanto, as ordens de serviço dos trabalhadores da empresa terceirizada que estavam trabalhando junto com o trabalhador próprio não previam o risco de atropelamento e nem a adoção de medidas de proteção.

Cabe registrar que apesar de existirem prescrições que referem o direito de recusa em situação de risco "ou dúvidas em relação à segurança" a investigação não encontrou registros de exercício prático deste direito, seja entre os trabalhadores próprios, seja entre os trabalhadores terceirizados. Esses fatos, em associação com a condição de que o deslocamento realizado pelos trabalhadores na via surge como algo a ser feito depois que a tarefa que lhes fora atribuída já havia sido encerrada, representando apenas retorno ao local de estacionamento de seus carros, parecem suficientes para explicar que tal prescrição não podia ser assumida como barreira em tal acidente. Afinal, qual seria a" tarefa" cuja realização pudesse ser paralisada? 
Por fim, cabe destacar que as prescrições de segurança da empresa abordam de modo tangencial e superficial a interação entre tarefas, tão importante no caso da segurança de trabalhadores de manutenção, enquanto fator potencial de acidentes ou situação de risco de acidentes.

Os aspectos acima comentados ressaltam como uma das principais falhas da gestão de segurança, nesse caso, a não antecipação do risco de atropelamento na realização do teste de freios de novos trens. Os mesmos aspectos também sugerem que a identificação desse risco só seria possível se a equipe tivesse acesso antecipado à informação de que a mudança do local do teste era previsível ou se, diante da decisão de mudança do local a equipe fosse novamente acionada e em sua análise explorasse a possibilidade de atraso no encerramento do teste. Conforme revelado neste estudo, em suas análises de risco a equipe de segurança não explorava variabilidades de tarefas com suas respectivas implicações e, por sua vez, os setores envolvidos em decisões como as de mudança de locais de teste não comunicavam o ocorrido aos encarregados da gestão de segurança. Na prática, agiam desconsiderando que tais fatos pudessem afetar a segurança do sistema. Esse desconhecimento é crucial para a prevenção em situações de interações entre tarefas. Em situações assemelhadas é o acidente que vai informar à gestão de segurança a existência de interação entre as tarefas de manutenção e condução de trens.

Do ponto de vista da interface de trabalho próprio com trabalho de terceirizados e diante das distintas práticas de saúde e segurança da empresa própria em relação a empresas terceirizadas, não foi identificado treinamento para trabalhadores terceirizados, para apresentação dos perigos e riscos e medidas de proteção, bem como, não há evidências da análise da compatibilização dos programas de saúde e segurança do trabalho das empresas terceirizadas.

Apesar do técnico ter assinado termo de responsabilidade dos EPIs calça, jaqueta e colete refletivo, oito anos antes da data do acidente, não foi evidenciado que o colete refletivo estava em condições de uso após tantos anos. E em relação aos trabalhadores terceiros, não há evidências de recebimento do colete refletivo, que por hipótese, reforça o fato da empresa terceirizada desconhecer a necessidade do trabalhador ter que caminhar na ferrovia. 
Ainda no que se refere ao uso de EPI, apesar da obrigatoriedade do uso de EPIs, segundo a NR 9 que trata do Programa de Prevenção de Riscos Ambientais entre as medidas de proteção devem prevalecer a eliminação ou redução do agente causador dos riscos, seguidas por medidas de caráter administrativo ou de organização do trabalho e, em último caso, devem ser adotadas o uso de equipamentos de proteção individual. Ou seja, o fato dos trabalhadores não estarem utilizando colete refletivo não se justifica, por si só, como única causa do atropelamento.

No decorrer da pesquisa foi possível observar que a ferrovia pode ser liberada para o tráfego de trens imediatamente após a comunicação de término do serviço entre o trabalhador que está no campo e o controlador. Entretanto, o término do serviço pode não incluir a remoção dos trabalhadores dos locais que os exponham ao risco de atropelamento.

Ainda no contexto da comunicação, os controladores do $\mathrm{CCO}$ e os controladores do CIM não promoveram comunicação ágil com as vítimas diante o perigo. Por hipótese, o fato deles trabalharem com muitas informações de maneira dinâmica, associado ao cansaço do trabalho da madrugada e final de jornada podem ter contribuído com a falta de agilidade na comunicação. Em complemento, o estabelecimento do plano de emergência poderia ter favorecido o estabelecimento prévio da comunicação do perigo e dos meios de abandono do local perigoso.

De acordo com o relato do maquinista, o trem ainda continuou em movimento muitos metros entre o momento da visualização dos trabalhadores na via, com a respectiva frenagem e a efetiva parada da composição. Sendo assim, a parada do trem, com o intuito de evitar colisão, ocorreu exclusivamente pelo comando do maquinista, sem medida de proteção adicional.

Ainda no contexto da frenagem do trem, não foi evidenciado sistema que detecte a presença de trabalhadores na via e bloqueie o tráfego de trens na via.

Em relação ao Pátio $\mathrm{B}$, a posição geográfica do Pátio $\mathrm{B}$, ou seja, onde os trens foram estacionados após o teste, não oferece opções seguras de trajeto para os 
trabalhadores. Sendo assim, é necessário projetar o acesso de trabalhadores ao Pátio B (figura 17).

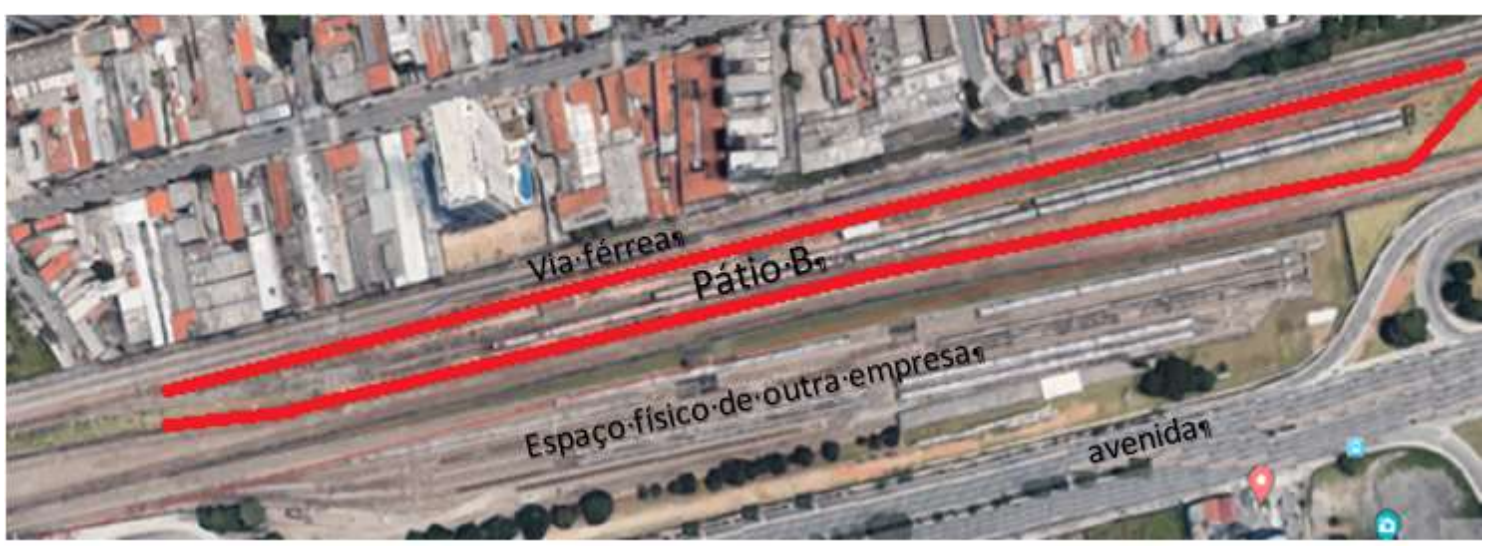

Fig. 17 Destacados em vermelho, os limites geográficos do Pátio B. FONTE: adaptado do GoogleMaps

Ainda no âmbito da disposição do Pátio $\mathrm{B}$, não foi evidenciada barreira física ou sinalização que indique o final do trecho da ferrovia que pertence ao Pátio e início do trecho operacional da ferrovia. (Figura 18).

Não foi evidenciado o uso de placas de sinalização indicando o perigo de atropelamento e a distância mínima dos trilhos para caminhar nas proximidades da via com segurança.

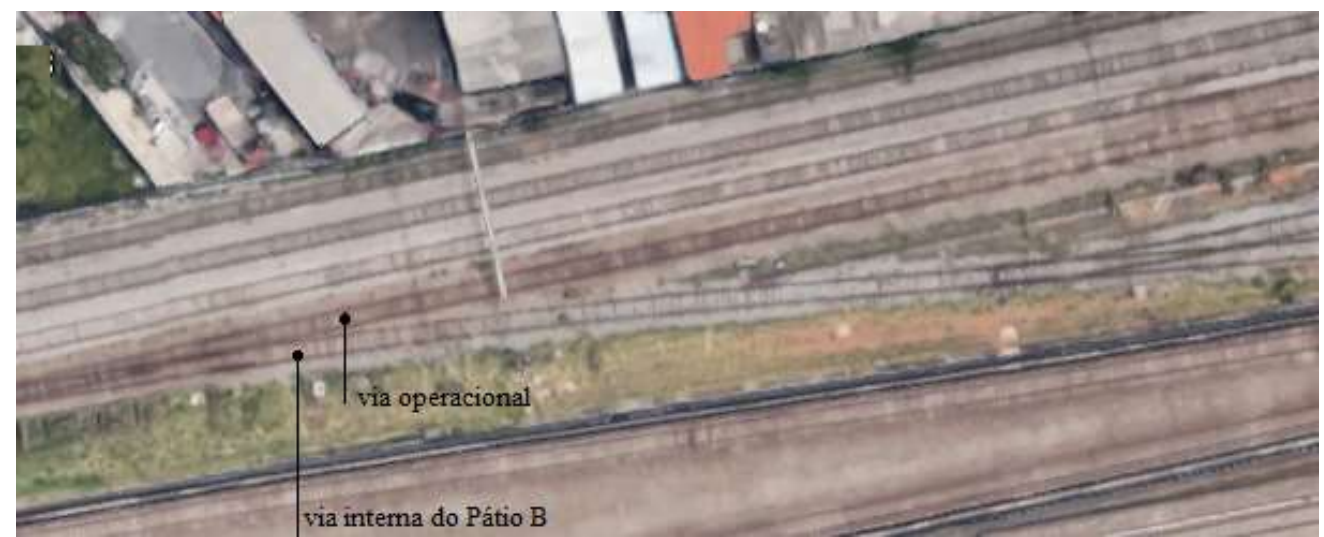

Fig. 18 Encontro da via férrea operacional e via interna do Pátio B FONTE: adaptado do GoogleMaps 
Diante do fato dos trabalhadores não poderem seguir de trem do Pátio B para o Pátio A, a opção seria caminhar pela faixa lindeira. Contudo, a faixa lindeira em direção ao Pátio A não favorecia o trajeto dos trabalhadores, devido aos inúmeros obstáculos existentes, como mostra a figura 19. A regularização do piso e a limpeza da faixa lindeira podem permitir o trajeto dos trabalhadores. Para tanto, é necessário que as caixas enterradas estejam com tampa, o piso esteja limpo e regularizado.

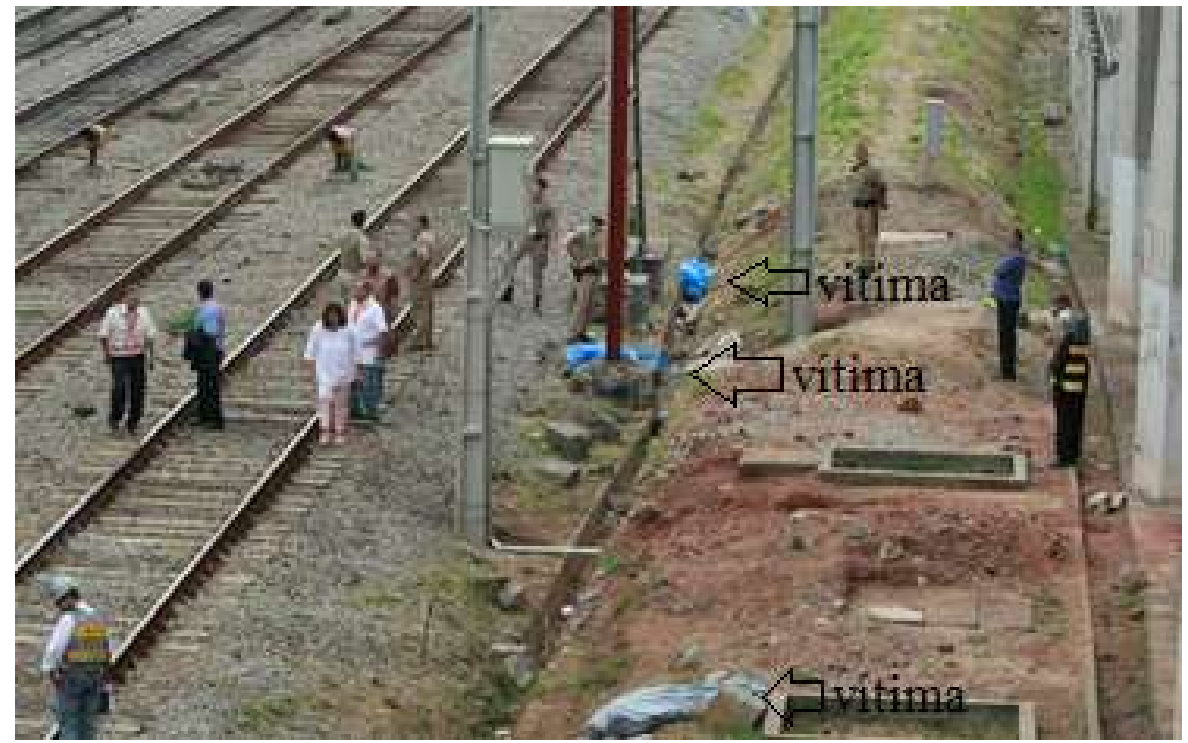

Fig.19 Foto da faixa lindeira no dia do acidente Fonte: adaptado de http://ultimosegundo.ig.com.br

\subsubsection{Síntese da Análise de Barreiras}

O quadro 3 mostra os principais aspectos identificados na análise de barreiras, considerando o perigo de atropelamento envolvido no acidente.

Os achados indicam falta e falha de barreiras associadas a falhas na gestão de segurança na sua interface com a gestão de produção. A abordagem prevalente na empresa privilegia explicação simplista e reducionista do fenômeno acidente, aparentemente reforçada mesmo diante de eventos, sinaliza fragilidade nas medidas de prevenção anteriormente escolhidas. 
Quadro 3 - Análise de barreiras.

\begin{tabular}{|c|c|c|c|c|}
\hline \multirow[b]{2}{*}{ Perigo } & \multicolumn{3}{|l|}{ Barreiras } & \multirow[b]{2}{*}{ Observação } \\
\hline & Recomendadas & Presentes & $\begin{array}{l}\text { Falta ou } \\
\text { Falha }\end{array}$ & \\
\hline \multirow{11}{*}{$\begin{array}{l}\text { Atropelamento / } \\
\text { interação entre } \\
\text { tarefas }\end{array}$} & $\begin{array}{l}\text { Análise de risco da } \\
\text { tarefa }\end{array}$ & Não & Falta & Apenas em serviços elétricos \\
\hline & Ordem de serviço & Sim & Falha & $\begin{array}{l}\text { Ordem de serviço dos } \\
\text { trabalhadores terceiros não } \\
\text { previa o risco de } \\
\text { atropelamento }\end{array}$ \\
\hline & Direito de recusa & Sim & Falha & $\begin{array}{l}\text { O serviço já tinha sido } \\
\text { encerrado }\end{array}$ \\
\hline & $\begin{array}{l}\text { Gestão da } \\
\text { segurança do } \\
\text { trabalho das } \\
\text { empresas } \\
\text { terceirizados }\end{array}$ & $\operatorname{Sim}$ & Falha & $\begin{array}{l}\text { Não explora as variabilidades } \\
\text { Não antecipa o risco de } \\
\text { atropelamento. } \\
\text { Gestão da interação entre } \\
\text { tarefas. } \\
\text { Gestão dos programas de } \\
\text { saúde e segurança do trabalho }\end{array}$ \\
\hline & \multirow{2}{*}{ Colete refletivo } & \multirow{2}{*}{ Não } & Falha & $\begin{array}{l}\text { Falha no controle da vida útil } \\
\text { do EPI }\end{array}$ \\
\hline & & & Falta & $\begin{array}{l}\text { Terceirizados não tinham } \\
\text { colete refletivo }\end{array}$ \\
\hline & Sinalização da via & Não & Falta & $\begin{array}{l}\text { Não evidenciada sinalização } \\
\text { para alertar o início de trecho } \\
\text { operacional. } \\
\text { Não evidenciada sinalização } \\
\text { de distância mínima do trilho } \\
\text { para caminhar com segurança. }\end{array}$ \\
\hline & $\begin{array}{l}\text { Comunicação da } \\
\text { saída da área de } \\
\text { risco }\end{array}$ & Não & Falta & $\begin{array}{l}\text { A comunicação com o Centro } \\
\text { de Controle ocorre após a } \\
\text { conclusão da tarefa. } \\
\text { Não evidenciada comunicação } \\
\text { após a saída do trabalhador da } \\
\text { área de risco de } \\
\text { atropelamento. }\end{array}$ \\
\hline & $\begin{array}{l}\text { Plano de } \\
\text { emergência }\end{array}$ & Não & Falta & $\begin{array}{l}\text { Não evidenciada comunicação } \\
\text { ágil, quando há perigo. } \\
\text { Estabelecimento dos meios de } \\
\text { abandono. }\end{array}$ \\
\hline & $\begin{array}{l}\text { Meio seguro de } \\
\text { acesso ao Pátio B }\end{array}$ & Não & Falta & Sem opção segura de trajeto. \\
\hline & $\begin{array}{l}\text { Regularização do } \\
\text { piso e limpeza da } \\
\text { faixa lindeira }\end{array}$ & Não & Falta & $\begin{array}{l}\text { A faixa lindeira era } \\
\text { intransitável }\end{array}$ \\
\hline
\end{tabular}

Os perigos como colisão entre composições, quedas, choques elétricos, incêndios entre outros, não são aqui explorados, pois o estudo consiste na análise de acidentes por atropelamento. 


\subsection{ANÁLISE DE MUDANÇAS}

Nesse ponto da análise são exploradas mudanças presentes nos componentes do sistema de atividade e as interações com o ambiente.

A realização de testes de freios é uma atividade eventual. Por hipótese, os dois novos trens marcaram o início da entrega prevista no contrato.

Os novos trens que seriam testados estavam estacionados conforme informação contida no e-mail, ou seja, no Pátio B. Entretanto, as vítimas se encontraram no Pátio A, conforme dados contidos no formulário interno. Por hipótese, a mudança de pátio pode estar atrelada ao fato do Pátio A não ter espaço para receber os trens em teste, visto que o Pátio A também é utilizado como oficina. Em complemento, segundo relatos dos entrevistados, o final de ano costumava ter maior demanda de manutenção dos trens devido à época de chuva e ao calor e, por consequência, os Pátios e Oficinas podem estar mais lotados, ainda mais na época do início da modernização dos trens.

Diante da mudança do local dos trens, surgiu a necessidade do grupo se deslocar para o Pátio B. A necessidade de encontrar um trem de serviço disponível para levar as oito pessoas ao pátio $\mathrm{B}$, atrasou o início da tarefa em 45 minutos. Com isso, a tarefa foi finalizada cerca de 10 minutos antes do início operacional dos trens, ao invés de terminar 30 minutos antes.

Em relação aos trabalhadores terceirizados, como não estavam familiarizados com o local do acidente, a testemunha que sobreviveu ao acidente, relatou que imaginava que após os testes seriam deixados no Pátio A e que só entendeu que estava caminhando na via comercial, após ter visualizado foto aérea do local do acidente.

Os maquinistas dos novos trens não caminharam na mesma direção das vítimas. Tais maquinistas adotaram caminho perigoso, pois tiveram que andar em faixa lindeira estreita, além de terem cruzado a via para chegar à Estação de Trem mais próxima. Caminhar pela via parece ser prática realizada anteriormente, reforçando a ausência de comunicação de perigo dos maquinistas para as vítimas. 


\subsubsection{Síntese da Análise de Mudanças}

O quadro 4 mostra os principais aspectos identificados na análise de mudanças, considerando o perigo de atropelamento envolvido no acidente.

Quadro 4 - Análise de mudanças.

\begin{tabular}{|l|l|}
\hline Mudança: & Comentários \\
\hline $\begin{array}{l}\text { Teste de freios em } \\
\text { trens novos }\end{array}$ & $\begin{array}{l}\text { Origem no contrato de aquisição de novos trens. } \\
\text { Por hipótese, início dos testes dinâmico do contrato. }\end{array}$ \\
\hline $\begin{array}{l}\text { Mudança de local do } \\
\text { teste }\end{array}$ & $\begin{array}{l}\text { Razões aparentes no fato do Pátio A estar lotado. } \\
\text { Cria a necessidade de deslocamentos e riscos não antecipados. }\end{array}$ \\
\hline $\begin{array}{l}\text { Comunicação da } \\
\text { mudança do local do } \\
\text { teste }\end{array}$ & $\begin{array}{l}\text { Importante esclarecer por que razões a equipe só foi informada ao chegar no } \\
\text { pátio A. }\end{array}$ \\
\hline $\begin{array}{l}\text { Atraso no término do } \\
\text { serviço }\end{array}$ & Aparentemente foi devido ao atraso no horário de início do teste. \\
\hline $\begin{array}{l}\text { Decisão do trajeto } \\
\text { após a conclusão do } \\
\text { teste }\end{array}$ & $\begin{array}{l}\text { O trajeto não foi planejado no momento da definição do uso do Pátio B para } \\
\text { estacionar os trens. } \\
\text { O trajeto do Pátio B até a Estação mais próxima. }\end{array}$ \\
\hline $\begin{array}{l}\text { Trabalhadores } \\
\text { terceiros não } \\
\text { conheciam o local }\end{array}$ & $\begin{array}{l}\text { A maior parte das vítimas não conhecia o trecho da ferrovia e os limites da } \\
\text { via interna do Pátio B. }\end{array}$ \\
\hline
\end{tabular}

Em síntese, os achados indicam fragilidades no planejamento das tarefas, em especial as tarefas que exigem interface com outros setores e empresas.

\subsection{AMPLIAÇÃO CONCEITUAL}

As vítimas foram atropeladas pelas costas e estavam caminhando na via olhando para frente, segundo a gravação do acidente. Por hipótese, se o trem envolvido no acidente estivesse trafegando na mão americana (figura 20), ou seja, no mesmo padrão da via onde os mesmos costumavam trabalhar, ao invés da mão inglesa (figura 21), as vítimas poderiam ter avistado a iluminação do trem. A forma de agir do mesmo modo a que 
estavam habituados é descrita na literatura como invasão do habitual (Reason \& Hobbs, 2003 ) e pode ter contribuído como armadilha cognitiva na situação desse acidente.

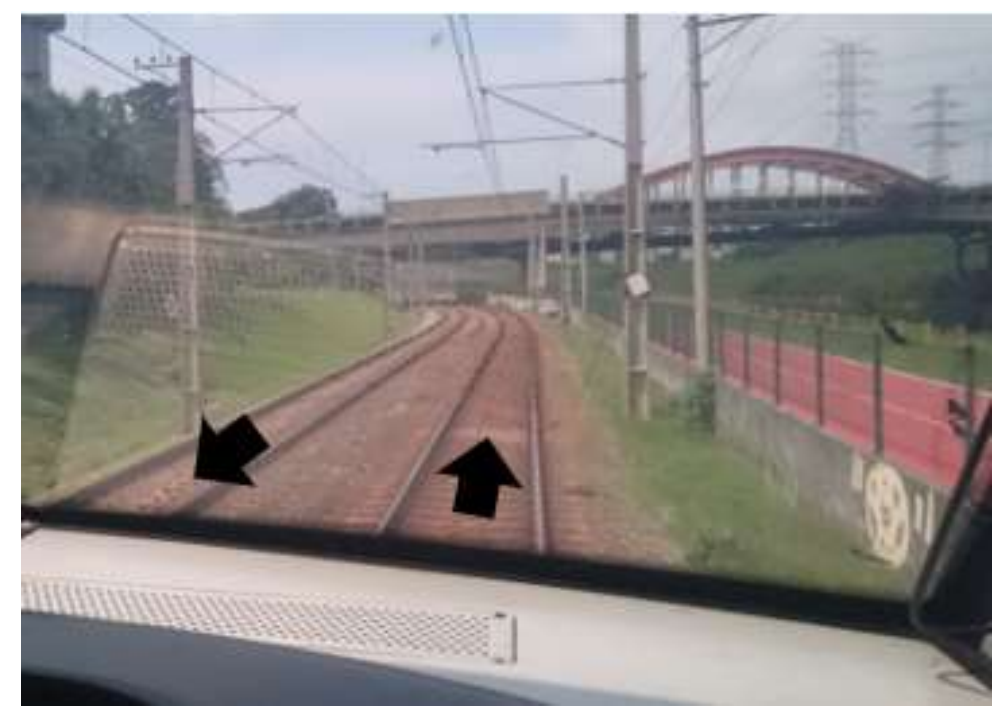

Fig. 20 - Sentido contrário - mão americana FONTE: a autora

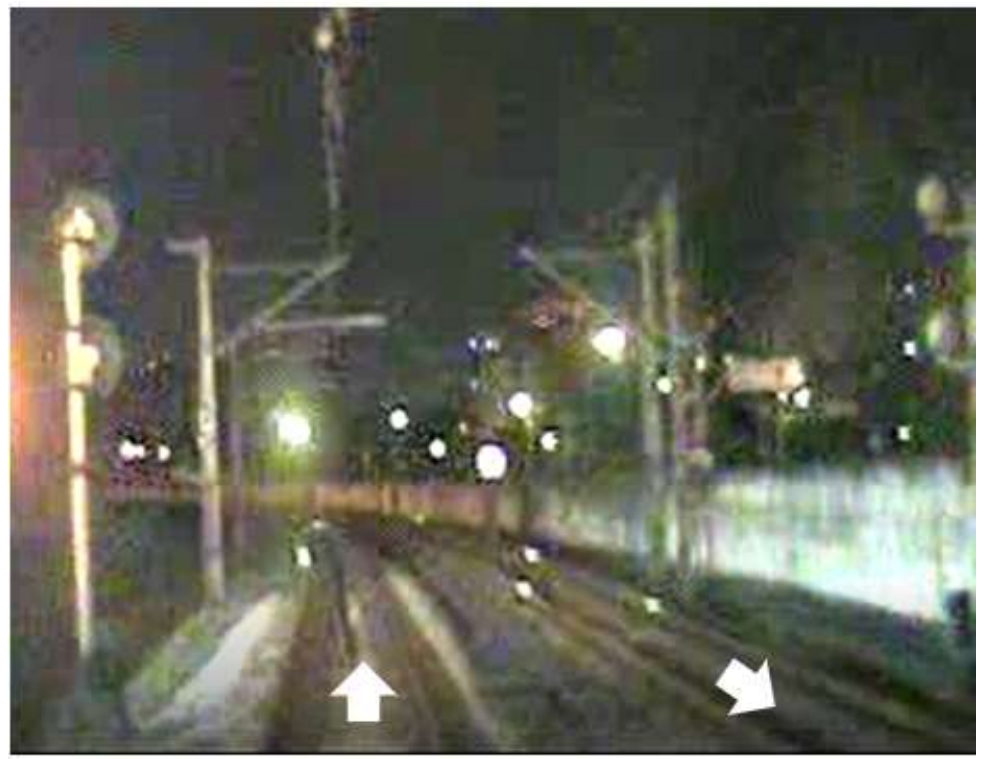

Fig. 21 - Sentido do trem no dia do acidente - Mão inglesa FONTE: adaptado do vídeo gravado pelo trem envolvido no acidente 
O caminho percorrido pelos acidentados, segundo relato do sobrevivente, aparentava ser via interna, ou seja, não aparentava ser via comercial, o que pode ter criado armadilha cognitiva devido à falsa sensação de segurança.

A representação do acidente de trabalho no modelo da gravata-borboleta (Hale et al, 2007) ajuda explicar que o atropelamento não se encerra no momento do acidente. Ao estudar o lado esquerdo da gravata borboleta, os históricos de atropelamentos ocorridos com trabalhadores terceiros e de colisões entre trens não foram suficientes para aprendizado significativo, que se refletisse em medidas de prevenção desse tipo de ocorrências no sistema.

\subsubsection{Síntese da Ampliação Conceitual}

Em síntese, a ampliação conceitual mostrou possível invasão do habitual, armadilhas cognitivas e falha na gestão da prevenção de acidentes (quadro 5).

Quadro 5 - Quadro síntese da ampliação conceitual

\begin{tabular}{|l|l|}
\hline Fatos que podem se beneficiar da & Conceitos potencialmente úteis na exploração dos fatos \\
\hline $\begin{array}{l}\text { Trabalhadores caminham por via } \\
\text { férrea no mesmo sentido do trem } \\
\text { envolvido no acidente }\end{array}$ & $\begin{array}{l}\text { Armadilha cognitiva com invasão do habitual. } \\
\text { As vitimas foram atingidas pelas costas }\end{array}$ \\
\hline $\begin{array}{l}\text { O sobrevivente alegou que não } \\
\text { sabia que a via era comercial }\end{array}$ & Armadilha cognitiva \\
\hline Histórico de acidentes & $\begin{array}{l}\text { Não auxiliou como alerta quanto a necessidade de melhoria na } \\
\text { prevenção de acidentes. }\end{array}$ \\
\hline
\end{tabular}

O uso do MAPA permitiu que fosse trilhada a análise do acidente de trabalho em profundidade em sistema complexo, e explicou o evento como fenômeno sócio-técnico com origens na história do sistema e extrapolou a conclusão do acidente obtida anteriormente (quadro 6). 
Quadro 6 - Resumo das análises realizadas por Instituições ou Comissões

\begin{tabular}{|c|c|}
\hline $\begin{array}{l}\text { Instituição ou } \\
\text { Comissão }\end{array}$ & Resumo da análise realizada pela Instituição \\
\hline $\begin{array}{l}\text { Sindicância da } \\
\text { empresa }\end{array}$ & $\begin{array}{l}\text { Houve falha humana. } \\
\text { Ocorreu imprudência e desatenção ao caminhar pela via. } \\
\text { Trabalhadores descumpriram os procedimentos. }\end{array}$ \\
\hline CIPA & As vítimas não utilizaram EPI \\
\hline \multirow[t]{4}{*}{ Instituição A } & $\begin{array}{l}\text { Recebeu a informação que as vítimas deveriam ter utilizado a faixa lindeira. } \\
\text { No entanto, a vistoria realizada pela equipe de vigilância identificou a } \\
\text { presença de buracos, postes e material de obra e obstruções de passagem na } \\
\text { faixa lindeira }\end{array}$ \\
\hline & $\begin{array}{l}\text { Identificou que Pátio B não permite acesso externo e que o Pátio A estava } \\
\text { lotado. }\end{array}$ \\
\hline & $\begin{array}{l}\text { Identificou que o empregado próprio trabalhava em via férrea com outras } \\
\text { características. }\end{array}$ \\
\hline & Apontou que as vítimas não tinham conhecimento do risco. \\
\hline \multirow[t]{5}{*}{ Instituição B } & $\begin{array}{l}\text { Apontou inexistência ou inadequação de sistema de permissão de trabalho } \\
\text { para acessar a via férrea }\end{array}$ \\
\hline & $\begin{array}{l}\text { Apontou falha / inadequação no subsistema de segurança, pois não havia } \\
\text { sistema que impedisse de forma eficiente o acesso aos trilhos }\end{array}$ \\
\hline & $\begin{array}{l}\text { Identificou ausência / insuficiência de supervisão, quanto à segurança dos } \\
\text { empregados próprios e terceirizados }\end{array}$ \\
\hline & $\begin{array}{l}\text { Indicou que não foi apresentado procedimento de trabalho com ênfase na } \\
\text { segurança do trabalho no acesso à via para a atividade }\end{array}$ \\
\hline & Indicou que não havia análise de risco par a tarefa \\
\hline
\end{tabular}




\section{CONSIDERAÇÕES FINAIS}

O estudo demonstrou que a abordagem organizacional na análise de acidente de trabalho ultrapassa o conceito de culpa da vítima, uma vez que o acidente é fruto da interação de várias atividades.

A atividade de produção de bens e serviços compreende um conjunto de interações e mediações entre o sujeito, os operadores e seu objeto. Nestas mediações estão incluídos: os instrumentos materiais e conceituais; as regras internas e externas; a divisão de trabalho que inclui os diferentes departamentos e a hierarquia; a comunidade que inclui a clientela e outros atores que partilham direta ou indiretamente o mesmo objeto (Engeström, 1987). A visão dialética e sistêmica permite que o sistema não seja compreendido por um componente isolado e sim pelo conjunto de suas interações. O acidente é visto como resultado inesperado de contradições que estão presentes há muito tempo neste sistema. Deste modo sua prevenção implica que os atores internos precisam identificar e sanear estas contradições.

Quando o acidente de trabalho é tratado como evento causado por um único elemento do sistema, como a falha na conduta do trabalhador, a organização amputa a análise e perde a oportunidade de aprender e melhorar seu desempenho, pois todos os outros elementos do sistema ficam às escuras. A empresa deixa de identificar oportunidades de melhoria e aprendizado organizacional, além de não tratar os múltiplos aspectos que contribuíram para a ocorrência do evento.

Esse estudo também contribuiu com a hipótese de que seguir estritamente o prescrito pode ser inviável e ou insuficiente para garantir o trabalho seguro. As prescrições são incapazes de antecipar toda a complexidade do real e podem deixar de considerar interações novas entre setores distintos que necessitam trabalhar em sintonia, em especial quando estão presentes trabalhadores da produção, manutenção e terceiros. Por outro lado, a gestão das comunicações precisa considerar as necessidades de informação das partes envolvidas, como instrumento de cooperação de trabalho. 
Elaborar procedimentos e esperar que os trabalhadores fiquem em estado de alerta constante ao longo de toda a jornada desconsidera as características físiológicas e psíquicas dos seres humanos. A adoção de redundância nas barreiras contribui com o controle e a regulação humana, pois se um sistema falhar, o outro sistema supre a falha. Além disso, barreiras para mitigar os efeitos tardios e de longo prazo também precisam ser estabelecidas.

Após o uso do MAPA na análise do acidente de trabalho, recomenda-se que a empresa estabeleça um Programa de Prevenção de Atropelamentos que leve em consideração as variabilidades nas tarefas, a interação dos diversos setores da empresa com empresas terceiras e a antecipação do reconhecimento do risco.

Outra recomendação para a prevenção de novos acidentes do trabalho por atropelamento é que os trabalhadores, dos mais diferentes níveis hierárquicos, passem a ter voz ativa no planejamento das tarefas e na definição de medidas de prevenção de acidentes.

O estudo apresenta hipóteses que ainda necessitam ser testadas e enriquecidas por meio de processo participativo, que confronte os diferentes pontos de vista, que construa e teste soluções sustentadas para a prevenção de novas ocorrências. A ideia de que pesquisador externo mesmo dotado de abordagem sociotécnica e sistêmica, possa construir sozinho um diagnóstico e recomendações, sem a confrontação com as diferentes vozes do sistema, precisa ser vista com cautela.

A aplicação do MAPA de maneira participativa é essencial para o aprendizado organizacional e pode trazer ricas contribuições do ponto de vista prevencionista no ambiente de trabalho.

O aprendizado expansivo e sistêmico necessariamente deve ocorrer com o coletivo de trabalho. Ele implica que os atores da organização percorram o ciclo de aprendizado que integre num mesmo processo o reconhecimento dos problemas, a análise de contradições que estão por trás dos eventos, a criação e o teste pelos envolvidos de soluções sustentadas para a segurança. Este caminho está em curso na empresa com a 
negociação de pesquisa colaborativa usando a metodologia do Laboratório de Mudanças (Virkkunen \& Newnham, 2013). 


\section{REFERÊNCIAS}

ALMEIDA, I., M.; VILELA, R.A.G. Modelo de análise e prevenção de acidentes de trabalho - MAPA. Piracicaba: CEREST Piracicaba: 2010. 52 p.

ALMEIDA, I. M. et al. Model of Analysis and Prevention of Accidents - MAPA: tool for operational health surveillance. Ciência \& saúde coletiva, v. 19, n. 12, p. 4679, 2014.

ALMEIDA, I.M.; VILELA, R.A.G.; SILVA, A.J.N.; BELTRAN, S.L. Modelo de análise e prevenção de acidentes - MAPA ferramenta para a vigilância em Saúde do trabalhador. Ciência \& Saúde Coletiva. ABRASCO - Associação Brasileira de Saúde Coletiva, v. 19, n. 12, p. 4679-4688, 2014. Disponível em:

$<$ http://hdl.handle.net/11449/114488>. Acesso em 02.dez.2016

AMALBERTI, R. Gestão da segurança. Presidente Prudente, 2016. 158 p

ANPTrilhos divulga 3a fase da campanha de valorização do transporte urbano sobre trilhos. ANPTrilhos, Brasilia, nov. 2016. Disponível em: $<$

http://anptrilhos.org.br/anptrilhos-divulga-3a-fase-da-campanha-de-valorizacao-dotransporte-urbano-sobre-trilhos/>. Acesso em: 10 dez. 2016

AREOSA, J. As perceções de riscos ocupacionais no setor ferroviário.Revista

Sociologia Problemas e Práticas, v.75, p.83-107, 2014. Disponível em

$<\mathrm{http}: / /$ spp.revues.org/1568>. Acesso em: 05 jul.2016

AREOSA, J. O lado obscuro dos acidentes de trabalho. Um estudo de caso no setor ferroviário. Braga: Edições Húmus, 2012. 199 p.

BALAGO, R. Veja fatos que marcaram a criação do Bilhete Único desde os anos 1990. Folha de S. Paulo, São Paulo, 10 ago. 2014. Disponível em <

http://www1.folha.uol.com.br/saopaulo/2014/08/1497671-veja-fatos-que-marcaram-acriacao-do-bilhete-unico-desde-os-anos-1990.shtml>. Acesso em: 15 out.2017

CARVALHO, J .P. CPTM demite condutor de trem após fim da sindicância. Estadão, São Paulo, 30.ago.2011. Disponível em: <

http:/www.estadao.com.br/noticias/geral,cptm-demite-condutor-de-trem-apos-fim-desindicancia,766245>. Acesso em: 03 set. 2017 
CBTU. Relatório de gestão. 2015. Disponível em

$<$ http://www.cbtu.gov.br/index.php/pt/desempenho/relatorios-anuais $>$. Acesso em: 20 abr.2016

CHAVDA, S.Sickness absence of LU train drivers after track incidents.Occupational Medicine. Jul. 2016. Disponível em<

http://occmed.oxfordjournals.org/content/early/2016/07/13/occmed.kqw088.abstract>. Acesso em: 15 ago.2016

COLISÃO entre dois trens da CPTM deixa quatro feridos em Itapevi. Estadão, São Paulo, 26.jan.2012. Disponível em: < http://sao-

paulo.estadao.com.br/noticias/geral,colisao-entre-dois-trens-da-cptm-deixa-quatroferidos-em-itapevi-sp,827718>. Acesso em: 03 set. 2017

COLISÃO entre trens da Linha 7 na Estação Luz, em São Paulo, provoca atraso na circulação. Folha, São Paulo, 26.jan.2012. Disponível em: <

http://www1.folha.uol.com.br/cotidiano/2010/12/850019-colisao-entre-trens-da-linha-7na-estacao-luz-em-sp-provoca-atraso-na-circulacao.shtml >. Acesso em: 03 set. 2017

COLISÃO entre trens da CPTM em Francisco Morato deixa 24 feridos. Valor, São Paulo, 18.dez.2012. Disponível em: < http://www.valor.com.br/brasil/2944480/colisaoentre-trens-da-cptm-em-francisco-morato-deixa-24-feridos>. Acesso em: 03 set. 2017

CPTM. Relatório de Administração. 2015. Disponível em $<$ http://www.cptm.sp.gov.br/a-companhia/Pages/Balancos-e-Demonstrativos.aspx $>$. Acesso em: 20 ago. 2016

CTB. Relatório de Gestão. 2015. Disponível em $<$ http://www.ctb.ba.gov.br/modules/conteudo/conteudo.php?conteudo=53>. Acesso em: 20 ago. 2016

DANIELLOU, F; SIMARD,M; BOISSIÈRES, I. Fatores humanos e organizacionais da segurança industrial. Foncsi, 2010.115 p

DONATELLI, S. Análise dos acidentes com material biológico em hospital universitário: uma abordagem a partir da análise das atividades de trabalho. Dissertação de mestrado. Universidade de São Paulo, Faculdade de Saúde Pública da USP, 2013 
ERA. Railway Safety Performance in the European Union. 2016. Disponível em $<$ http://www.era.europa.eu/Document-

Register/Documents/Railway\%20Safety\%20Performance\%202016\%20final\%20E.pdf> . Acesso em: 10 set.2016

ESPANHOL está entre mortos atropelados por trem da CPTM, Folha, São Paulo < http://www1.folha.uol.com.br/cotidiano/2011/11/1012898-espanhol-esta-entre-mortosatropelados-por-trem-da-cptm.shtml >. Acesso em: 15 set.2017

FALHA humana causou acidente entre trens em SP, diz secretário, G1, São Paulo, 15.fev.2012. Disponível em: < http://g1.globo.com/sao-paulo/noticia/2012/02/falhahumana-causou-acidente-entre-trens-em-sp-diz-secretario.html $>$. Acesso em: 03 set. 2017

FISCHER, D.; GUIMARÃES, L.B.M., VENTER, L; BATISTA Análise de acidentes do trabalho típicos envolvendo operadores de trem urbano. In: XIII Congresso Brasileiro de Ergonomia, 2004, Fortaleza. Anais...Fortaleza:ABERGO, 2004. P. Disponível em $<$ http://www.producao.ufrgs.br/arquivos/publicacoes/92_21_Lia_Abergo2004.pdf $>$. Acesso em: 23 dez.2016

GONSALVES, M.; SPIGLIATTI, S. Dois trens da CPTM batem na Estação Barra Funda, em São Paulo. Estadão, São Paulo, 12.jul.2011. Disponível em: < http://saopaulo.estadao.com.br/noticias/geral,dois-trens-da-cptm-batem-na-estacao-barra-fundaem-sao-paulo,743958>. Acesso em: 03 set. 2017

GROSTEIN, M. D. Periferias metropolitanas em nova escala: um novo ciclo da urbanização em São Paulo. Revista Iberoamericana de Urbanismo, Barcelona, n. 12, p.33-52, 2015. Disponível em: <http://www.riurb.com/n12/12_02_Grostein.pdf.>. Acesso em 12 abr 2016.

HALE AR, ALE BJM, GOOSSENS LHJ, HEIJER T, BELLAMU LJ, MUD ML, ROELEN A, BASKSTEEN H, POST J, PPAZOGLOU IA, BLOEMHOFF A, OH JIH., Modeling accidents for prioritizing prevention. Reliability engineering and system safety pp. 1701-1715, 2007.

HOLLNAGEL, E. Safety-I and Safety-II: the past and future of safety management. Famham: Ashgate, 2014187 p. 
HURTADO, S.L.B (2016). Análise de acidente de trabalho em uma refinaria de petróleo: desencontros entre a segurança comportamental e organizacional. 2016. Dissertação de mestrado. Universidade de São Paulo, Faculdade de Saúde Pública da USP, 2016

INTEGRAÇÃO gratuita da Linha Amarela do Metrô com a CPTM começa nesta quinta-feira. Uol. São Paulo, 01 jun 2011. Disponível em < https://noticias.uol.com.br/cotidiano/ultimas-noticias/2011/06/01/integracao-gratuita-dalinha-amarela-do-metro-com-a-cptm-comeca-nesta-quinta-feira.htm>. Acesso em 15 out 2017

JACINTO, C.; SILVA, C. A semi-quantitative assessment of occupational risks using bow-tie representation. Safety Science v.48 p. 973-979., 2010 Disponível em: < http://www.sciencedirect.com/science/article/pii/S0925753509002045>. Acesso em 23 dez.2016

JACKSON FILHO, J.M.; LIMA, F.P.A. Analise Ergonômica do Trabalho no Brasil: transferência tecnológica bem-sucedida? Revista Brasileira de Saúde Ocupacional v.40, n.131. 2015. Disponível em:

$<$ http://www.scielo.br/scielo.php?script=sci arttext\&pid=S0303-76572015000100012 $>$. Acesso em 23.dez.2016

JACKSON FILHO, J.M.; VILELA, R.A.G.; GARCIA, E.G.; ALMEIDA, I. M. Sobre a "aceitabilidade social" dos acidentes do trabalho e o inaceitável conceito de ato inseguro. Revista Brasileira de Saúde Ocupacional, v. 38, n.127, p. 6-8, 2013. Disponível em: $<$ http://www.scielo.br/scielo.php?script=sci_arttext\&pid=S030376572013000100001>. Acesso em 02 dez.2016

LIMA, FRANCISCO P.A.; Rabelo, Lais D B C (Org.); LARA, Marcelle L. G. (Org.). Conectando saberes: dispositivos sociais de prevenção de acidentes e doenças no trabalho. 1. ed. Belo horizonte: Fabrefactum, 2015. v. 1. 350p.

LINHA da CPTM é liberada após acidente envolvendo dois trens. R7, São Paulo < http://noticias.r7.com/sao-paulo/noticias/linha-da-cptm-e-liberada-apos-acidenteenvolvendo-dois-trens-20110712.html>. Acesso em 15 set.2017

LLORY, M.; MONTMAYEUL, R. O acidente e a organização. São Paulo: Editora Atlas, 2010.311 p. 
LOPES, M.G.R. (2012). Risco nas passagens de nível ferroviárias: lições do caso do acidente de Americana-SP. 2012. Dissertação de mestrado. Universidade de São Paulo, Faculdade de Saúde Pública da USP, 2012

MARCONI, M.A; LAKATOS, E.M. Fundamentos de metodologia científica. Belo Horizonte: Fabrefactum, 2014.157 p.

MINISTÉRIO DO TRABALHO E PREVIDÊNCIA SOCIAL. Anuário Estatístico de Acidentes do Trabalho AEAT 2014. Brasilia: MTPS, 2014. Disponível em: $<$ ftp://ftp.mtps.gov.br/portal/acesso-a-informacao/AEAT201418.05.pdf $>$. Acesso em 01.nov.2016

PANTUZZO, C.H. Levantamento dos riscos existentes na manutenção da via permanente ferroviária. São Paulo: PECEUSP, 2015. p.61 Monografia - Programa de Educação Continuada da Escola Politécnica da Universidade de São Paulo, São Paulo, 2015.

REASON, J. Human error: models and management. The Western Journal of Medicine. V.172 p393, 2000

REASON. J; HOBBES, A. Managing maintenance error. A practical guide. Boca Raton. CRC Press. Taylor \& Francis Group, 2003.

SANTOS, J. C.;SOBRAL, M. F. F. Diagnóstico, perspectivas de uso e expansão dos serviços de trens metropolitanos no Brasil. Revista de Administração Pública, v.48, n.2, p. 481-506, 2014. Disponível em:

$<$ http://www.scielo.br/pdf/rap/v48n2/a10v48n2.pdf>. Acesso em 20.abr.2016

SEIXAS, J. J. T.; Sistema de Avaliação do Aprendizado de Procedimentos de Operação. Revista Ferroviária, São Paulo. Ed. 170. Pag.6. jan-jun.2016

SEGUNDO trecho da Linha 5-Lilás do Metrô de SP não saiu do papel. G1. São Paulo, 15 mai 2011. Disponível em <http://g1.globo.com/saopaulo/noticia/2011/05/segundo-trecho-da-linha-5-lilas-do-metro-de-sp-nao-saiu-dopapel.html>. Acesso em 15 out.2017. 
SOUZA, C. G.; FRATINI,W. Gestão de riscos: questão crucial para as operadoras metroferroviárias. Cadernos Técnicos: Transporte metroferroviário no Brasil, v. 2, 2005.Disponível em < http://filesserver.antp.org.br/5dotSystem/download/dcmDocument/2016/02/24/29C25B2592DD-445E-8EC6-28E020A3EDC9.pdf>. Acesso em: 23 ago.2016

SILVA, A.J.N. Análise organizacional de acidentes de trabalho no setor de distribuição de energia elétrica. 2015. Dissertação de mestrado. Universidade Estadual Paulista Júlio de Mesquita Filho, Faculdade de Medicina de Botucatu, 2015

SUPERVIA. Quem somos. Disponível em <http://www.supervia.com.br/ptbr/empresa/quem-somos $>$. Acesso em 15 jul.2016

TANI, M.K. Transporte sobre trilhos na Região Metropolitana de São Paulo: estudo sobre a concepção e inserção das redes de transporte de alta capacidade. São Paulo: FAUUSP. 2013.p.160 Dissertação - Programa de Mestrado em Arquitetura e Urbanismo, 2013.

TRENS da CPTM colidem na zona leste de São Paulo, Estadão, São Paulo, 08.dez.2011. Disponível em: < http://www.estadao.com.br/noticias/geral,trens-da-cptmcolidem-na-zona-leste-de-sp,651039>. Acesso em: 03 set. 2017

TRENSURB. A história. Disponível em $<$ http://www.trensurb.gov.br/paginas/paginas_detalhe.php?codigo_sitemap=48>. Acesso em: 15 jul.2016

VERGARA, S. C. Gestão de Pessoas. São Paulo: Atlas, 2012.

VILELA, R.A.G.; IGUTI, A.M.; ALMEIDA, I.M. Culpa da vítima: um modelo para perpetuar a impunidade nos acidentes do trabalho. Cadernos de Saúde Pública. Escola Nacional de Saúde Pública Sergio Arouca, Fundação Oswaldo Cruz, v. 20, n. 2, p. 570579, 2004. Disponível em: <http://hdl.handle.net/11449/13275>. Acesso em 05 dez.2016

YIN, R.K. Estudo de Caso: planejamento e método. 4. Ed., Porto Alegre: Bookman, 201, p.248.

VIRKKUNEN, J.; NEWNHAM, D. S. The Change Laboratory: a tool for collaborative developmental of work and education. Netherlands: Sense Publishers, 2013. 
ZANDONADE, P.; MORETTI, R. O padrão de mobilidade de São Paulo e o pressuposto de desigualdade. Revista Latinoamericana de Estudios Urbanos Regionales. v.38, n. 113, p. 77-97, 2012. Disponível em:

$<$ http://www.scielo.cl/scielo.php?pid=S0250-

$71612012000100004 \&$ script $=$ sci_arttext\&tlng=pt. $>$. Acesso em: 20.abr.2016 
APÊNDICE 


\section{Termo de responsabilidade sobre os esclarecimentos éticos usados na pesquisa}

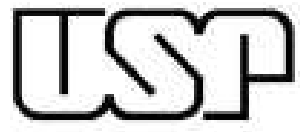

UNIVERSIDADE DE SÃO PAULO FACULDADE DE SAÚDE PÚBLICA

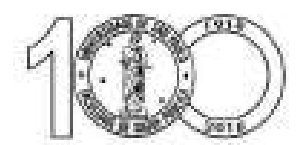

TERMO DE RESPONSABILIDADE SOBRE OS ESCLARECIMENTOS ÉTICOS USADOS NA PESQUISA

Esta pesquisa faz parte do projeto temático da FAPESP 2012/04721-1 intitulado "Acidente de Trabalho da análise sócio técnica à construção social de mudanças" coordenado pelo Prof. Dr. Rodolfo Andrade de Gouveia Vilela da Faculdade de Saude Pública da USP

Pesquisadora: Leandra Antunes

Título do Projeto: ANÁLISE DE ACIDENTE DO TRABALHO SOB UMA PERSPECTIVA ORGANIZACIONAL: ESTUDO DE CASO NO SETOR FERROVIÁRIO orientado pelo Prof. Dr. Ildeberto Muniz de Almeida - Programa de Mestrado Profissional em Ambiente, Saúde e Sustentabilidade da Faculdade de Saude Pública da USP

Este projeto tem como objetivos: a) contribuir para a segurança dos trabalhadores e dos usuários da CTPM em sintonia com a missão da empresa; b) conhecer as origens organizacionais e sistêmicas dos acidentes de trabalho e contribuir para substituição das explicações reducionistas (acidente causado por culpa da vítima); c) promover a cultura da prevenção que se sobrepõe a da reparação.

Para tanto será necessánio realizar os seguintes procedimentos: a) Análise de documentos; b) Entrevistas individuais e/ou coletivas; c) Observação e gravação da atividade; d) Reanálise de acidentes de trabalho com a aplicação do Modelo de Análise e Prevençâo de Acidentes de Trabalho (MAPA); e) Análise dos dados obtidos.

A execução do projeto oferece riscos minimos para os participantes. Para controlar e minimizar esses riscos, o pesquisador garante o anonimato dos participantes, sigilo das informações relacionadas à privacidade e a participação voluntária podendo deixar de participar da pesquisa em qualquer etapa.

O pesquisador estará a sua disposição para qualquer esclarecimento e assistência que considere necessário em qualquer etapa da pesquisa no telefone (11) 3061-7120, emails: ravilela@usp.bre leandraa@usp.br. 
Após ler e receber explicações sobre a pesquisa, fica assegurado os direitos dos participantes de:

1. receber resposta a qualquer pergunta e esclarecimento sobre os procedimentos, riscos, beneficios e outros relacionados à pesquisa;

2. deixar de participar do estudo a qualquer momento;

3. não ser identificado e ser mantido o caráter confidencial das informações relacionadas ả privacidade;

4. procurar esclarecimentos com o Comitê de Ética em Pesquisa da Faculdade de Saúde Pública da Universidade de São Paulo, no telefone 11 3061-7779 ou Av. Dr. Amaldo, 715 - Cerqueira César, São Paulo - SP, em caso de dúvidas ou notificação de acontecimentos não previstos;

5. o termo será emitido em duas vias e uma dessas será entregue ao participante da pesquisa.

$$
\text { de } \quad \text { de } 201
$$

$\mathrm{Eu}$,

R.G.:

declaro para os devidos fins que testemunhei a prestação dos esclarecimentos éticos contidos no presente termo de responsabilidade.

Assinatura do sujeito:

$\mathrm{Eu}$,

R.G.: declaro para os devidos fins que testemunhei a prestação dos esclarecimentos éticos contidos no presente termo de responsabilidade.

Assinatura do sujeito:

Eu, Leandra Antunes, declaro que fomeci todas as informações referentes ao projeto para o participante.

Leandra Antunes

Rodolfo Andrade de Gouveia Vilela

Pesquisador Responsável pelo Projeto: Professor Dr. Rodolfo Andrade de Gouveia Vilela da Faculdade de Saúde Pública da Universidade de São Paulo - Departamento de Saúde Ambiental. Av. Dr. Amaldo 715 - Saúde do Trabalhador, 20 andar. CEP 01246-904São Paulo - SP - Fone: (11) 3061-7120 